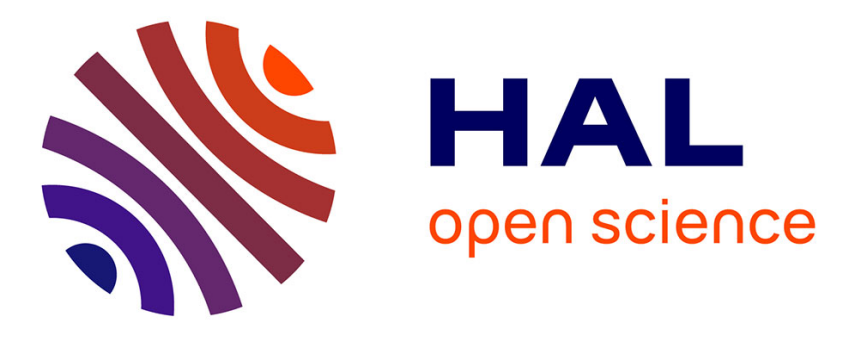

\title{
Impact of rare-earth elements on the corrosion performance of binary magnesium alloys
}

Hiba Azzeddine, Abdelkader Hanna, Achour Dakhouche, Lyacine Rabahi, Nico Scharnagl, Milan Dopita, François Brisset, Anne-Laure Helbert, Thierry Baudin

\section{To cite this version:}

Hiba Azzeddine, Abdelkader Hanna, Achour Dakhouche, Lyacine Rabahi, Nico Scharnagl, et al.. Impact of rare-earth elements on the corrosion performance of binary magnesium alloys. Journal of Alloys and Compounds, 2020, 829, pp.154569. 10.1016/j.jallcom.2020.154569 . hal-03009897

\section{HAL Id: hal-03009897 https://hal.science/hal-03009897}

Submitted on 2 Dec 2020

HAL is a multi-disciplinary open access archive for the deposit and dissemination of scientific research documents, whether they are published or not. The documents may come from teaching and research institutions in France or abroad, or from public or private research centers.
L'archive ouverte pluridisciplinaire HAL, est destinée au dépôt et à la diffusion de documents scientifiques de niveau recherche, publiés ou non, émanant des établissements d'enseignement et de recherche français ou étrangers, des laboratoires publics ou privés. 


\title{
Impact of rare-earth elements on the corrosion performance of binary magnesium alloys
}

\author{
Hiba Azzeddine ${ }^{1, *}$, Abdelkader Hanna ${ }^{1}$, Achour Dakhouche ${ }^{2}$, Lyacine Rabahi ${ }^{3,4}$,
} Nico Scharnagl ${ }^{5}$, Milan Dopita ${ }^{6}$, François Brisset $^{7}$, Anne-Laure Helbert $^{7}$, Thierry Baudin ${ }^{7}$

1 Department of Physics, Faculty of Sciences, University of Mohamed Boudiaf, M'sila, Algeria

2 Inorganic Materials Laboratory, Department of Chemistry, Faculty of Sciences, University of Mohamed Boudiaf, M'sila, Algeria

3 Laboratoire de Physique Théorique, Faculté de Physique, USTHB, BP 32, El Alia, 16111, Bab Ezzouar, Alger, Algeria

4 Research Center in Industrial Technologies CRTI. P.O. Box 64, Cheraga, Algiers, 16014, Algeria

5 Helmholtz-Zentrum Geesthacht Institute of Materials Research, Magnesium Innovation Centre - MagIC, , Max-Planck Str.1, 21502 Geesthacht , Germany

6 Department of Condensed Matter Physics, Charles University, Prague, Czech Republic

7 ICMMO, Univ. Paris-Sud, Université Paris-Saclay, UMR CNRS 8182, 91405 Orsay

Cedex, France

* Corresponding author: Dr. Hiba Azzeddine, e-mail: hiba.azzeddine@ univ-msila.dz

\begin{abstract}
The corrosion behaviour of $\mathrm{Mg}-0.3 \mathrm{Ce}, \mathrm{Mg}-0.41 \mathrm{Dy}, \mathrm{Mg}-0.63 \mathrm{Gd}, \mathrm{Mg}-1.44 \mathrm{Nd}$ and $\mathrm{Mg}-1.43 \mathrm{La}$ (wt.\%) alloys in 3.5 wt.\% NaCl solution was investigated using electrochemical tests. The ascast microstructures of the Mg-RE alloys were characterized by the presence of second phases $\left(\mathrm{Mg}_{\mathrm{x}} \mathrm{Ce}, \mathrm{Mg}_{41} \mathrm{Dy} 5, \mathrm{Mg}_{12} \mathrm{Gd}, \mathrm{Mg}_{12} \mathrm{Nd}, \mathrm{Mg}_{41} \mathrm{Nd}_{5}, \mathrm{Mg}_{24} \mathrm{Nd}\right.$ and $\mathrm{Mg}_{12} \mathrm{La}$ ) with different volume fraction and distribution. Results show that the corrosion mechanism was altered from uniform to localized corrosion mechanism depending on the specific RE alloying elements. The corrosion resistance of the Mg-RE alloys is increasing in the following order: $\mathrm{Mg}-1.43 \mathrm{La}$, Mg-1.44Nd, Mg-0.3Ce, Mg-0.63Gd and Mg-0.41Dy. Accordingly, the corrosion morphology in the best resistant $\mathrm{Mg}-0.41 \mathrm{Dy}$ alloy and the worst $\mathrm{Mg}-1.43 \mathrm{La}$ alloy were observed and compared after $2 \mathrm{~h}$ and $24 \mathrm{~h}$ of immersion using SEM-EDS, XPS and XRD analysis. The formation of the $\mathrm{Dy}_{2} \mathrm{O}_{3}$ oxide prevents the $\mathrm{Mg}-0.41 \mathrm{Dy}$ alloy from pitting corrosion and lead to an excellent corrosion surface even after $24 \mathrm{~h}$ of immersion. Meanwhile, the presence of a high fraction of the $\mathrm{Mg}_{12} \mathrm{La}$ phase along the grains boundaries in the $\mathrm{Mg}-1.43 \mathrm{La}$ alloy causes severe pitting corrosion by acting as anodic phase.
\end{abstract}


Keywords: Corrosion resistance; Chloride ion; Magnesium alloy; Rare earth element.

\section{Introduction}

During the last decades, the use of Magnesium $(\mathrm{Mg})$ based alloys as structure materials in automotive and aerospace industries have been increased due to their low density, high specific strength, high damping capacity, corrosion resistance and easy recyclability [1-3]. However, Mg-based alloys generally suffer from relatively poor corrosion resistance in the high chloride environment of physiological systems due to their low standard electrochemical potential $(-2.37 \mathrm{~V})$, as compared to the SHE (Standard Hydrogen Electrode) [4] which therefore restricts their use in a variety of applications [5-7]. The poor corrosion resistance of Mg-based alloys was attributed to the internal galvanic corrosion by inhomogeneous distribution of second phases or the presence of impurities elements such $\mathrm{Fe}, \mathrm{Ni}, \mathrm{Cu}$ and $\mathrm{Co}$ and the instability of the hydroxide film $(\mathrm{MgOH})_{2}$ that formed on the $\mathrm{Mg}$ surface $[5,6]$.

Many strategies have been proposed to improve the corrosion resistance of Mg-based alloys. Surface treatment by anodic coating is the most employed technique for improving the corrosion behaviour of Mg-based alloys [8-11]. Among the existing surface treatment methods, the plasma electrolytic oxidation (PEO) coating technique shows a remarkable increase in the corrosion resistance of $\mathrm{Mg}$ alloys by forming a relatively thick and crystalline oxide layer on the surface [8, 12-14].

Fabricate ultrafine-grained materials using severe plastic deformation (SPD) such as equal channel angular pressing (ECAP), high pressure torsion (HPT) and groove pressing (GP) have proven their effectiveness to improve the homogeneity of the microstructure of $\mathrm{Mg}$ alloys as well as their corrosion resistance by dissolution of impurities and accelerating passivity of Mg-based alloys [15-19]. However, the existing literature on the impact of the microstructure and the deformation processing on the corrosion behaviour is often contradictory [18]. The effect of the second phase distribution on corrosion behaviour, induced by mechanical processing, was found depending on the role of the second phase as anode or cathode [18]. For example, the presence of the net-like $\mathrm{Mg}_{41} \mathrm{Sm}_{5}$ phase in the as-cast $\mathrm{Mg}$-Sm-Zn-Zr alloy was found to act as a cathodic phase and thereby cause the galvanic corrosion [20]. While the decrease in the size of the same phase and its homogeneous distribution caused by the extrusion processing leads to more uniform corrosion [20].

Alloying elements are another effective strategy to enhance the mechanical properties and improve the corrosion resistance of Mg-based alloys. Recently, it was reported that rare earth 
(RE) elements have significant effects on the high temperature strength and creep resistance of Mg-based and can improve considerably their corrosion resistance [21-23]. Moreover, MgRE alloys are receiving increasing attention in biomedical applications as potential biodegradable implant materials due to their biodegradability and suitable mechanical properties [24]. However, some recent reports indicated that some $R E$ elements such as La and Ce elements should be used carefully because of the toxicity issues compared to the other $R E$ elements [25].

Several suppositions have been given to explain the benefic effect of $R E$ element on the corrosion behaviour of Mg-based alloys. Among of them: (i) $R E$ elements have the ability to reduce the effect of impurity by forming intermetallic compounds and purify the melt [26], (ii) $R E$ elements can reduce the amount of second phases and grain size, resulting in a much homogeneous microstructure which will decrease the probability of occurring the microgalvanic corrosion [27], (iii) $R E$ elements can reduce the hydration of the corrosion product film of Mg-based alloys and then improve the protective performance of the corrosion product [28], and (iv) $R E$ elements can decrease the $M g$ dissolution of the deformed alloys by decreasing the volume fraction of twins and dislocations density [29].

The results of electrochemical tests showed that the E21 and WE43 alloys exhibit higher corrosion resistance than the conventional AZ31(Mg-3Al-1Zn, wt.\%) alloy [8]. However, it was reported that the corrosion rate of binary $\mathrm{Mg}-\mathrm{RE}(\mathrm{RE}=\mathrm{Ce}, \mathrm{La}, \mathrm{Nd}, \mathrm{Y}$ and $\mathrm{Gd})$ was greater than that of pure $\mathrm{Mg}$ and it was attributed to the presence of second phase [27]. A binary high-pressure die-cast $\mathrm{Mg}$-Ce alloy was reported to exhibit a lower corrosion rate than binary $\mathrm{Mg}-\mathrm{Nd}$ and $\mathrm{Mg}-\mathrm{La}$ alloys in $0.1 \mathrm{M} \mathrm{NaCl}(\sim 0.6$ wt.\% $\mathrm{NaCl})$ solution [30]. Such difference in the corrosion rate was attributed to the effect of the specific $R E$ element contained in the second phase [30].

Up to now, the effect of different RE addition elements on the properties of second phases and their impact on the corrosion behaviour of Mg-based alloys are not fully understood and is more complicated than expected. Therefore, the objective of the present work is to elucidate the effect of a small content of $R E$ elements such as $\mathrm{Ce}, \mathrm{Dy}, \mathrm{Gd}, \mathrm{Nd}$ and $\mathrm{La}$ on the corrosion mechanism of binary $\mathrm{Mg}-\mathrm{RE}$ alloy in $3.5 \% \mathrm{NaCl}$ solution.

\section{Experimental procedure}

\subsection{Materials}

The as-cast $\mathrm{Mg}-0.3 \mathrm{Ce}, \mathrm{Mg}-0.41 \mathrm{Dy}, \mathrm{Mg}-0.63 \mathrm{Gd}, \mathrm{Mg}-1.44 \mathrm{Nd}$ and $\mathrm{Mg}-1.43 \mathrm{La}$ (wt.\%) alloys were kindly supplied by the Institute für Metallkunde und Metallphysik, Aachen, Germany. 
Accordingly, the alloys were produced by induction melting and casting under a protective gas atmosphere of $\mathrm{Ar} / \mathrm{CO}_{2}$ using a preheated copper mould. The as-cast alloys have undergone heat treatment at $420{ }^{\circ} \mathrm{C}$ for $20 \mathrm{~h}$ and then quenched in water.

\subsection{Electrochemical tests}

The immersion test was conducted in $3.5 \%$ (\% wt.) $\mathrm{NaCl}$ which was prepared at room temperature $\left(25^{\circ} \mathrm{C}\right)$ by dissolving the $\mathrm{NaCl}$ in distilled water.

Electrochemical tests were conducted using an AUTOLAB PGSTAT302N electrochemical work station and a standard three-electrode cell, wherein the sample is the working electrode, a platinum plate as the counter electrode, and a calomel electrode (SCE)(0.24 vs. SHE) is the reference electrode. The samples were embedded in an epoxy resin to isolate a $0.5 \mathrm{~cm}^{2}$ area from the non-studied surfaces and were then immersed in $3.5 \% \mathrm{NaCl}$ solution at room temperature. The open-circuit potential (OCP) was measured for at least $2 \mathrm{~h}$ for all samples. The polarization curves were recorded in the range of -2.6 to $0 \mathrm{~V}$ vs. SCE with a scan rate of $2 \mathrm{mV} \cdot \mathrm{s}^{-1}$. The impedance measurements were performed after the open circuit potential with a sinusoidal potential signal with an amplitude of $10 \mathrm{mV}$ in the frequency range from $10^{-2} \mathrm{~Hz}$ to $10^{5} \mathrm{~Hz}$. Experimental curves were fitted using ZView software. Three replicated tests were performed for each alloy to ensure reproducibility.

\subsection{Immersion test}

Cylindric samples with the $10 \mathrm{~mm}$ of diameter and $3 \mathrm{~mm}$ of thickness were exposed to $3.5 \%$ $\mathrm{NaCl}$ solution for $2 \mathrm{~h}$ and $24 \mathrm{~h}$ at room temperature. The ratio of sample surface area $\left(\mathrm{cm}^{2}\right)$ to the volume of $3.5 \% \mathrm{NaCl}$ solution $(\mathrm{mL})$ was set to $1: 100$. The $\mathrm{pH}$ value of the solution was measured using a calibrated $\mathrm{pH}$ meter.

\subsection{Microstructure characterization}

The initial microstructures were investigated by scanning electron microscopy (SEM, FEGSEM ZEISS Gemini) equipped with energy dispersive spectrometry (EDS) system in backscattering (BSE) mode operated at $15 \mathrm{kV}$. While, the morphology of the corrosion product was examined by SEM (TESCAN Vega 3 SB) using a range of $8-10 \mathrm{kV}$ as acceleration voltages.

The surface preparation consisted of grinding with progressively finer $\mathrm{SiC}$ paper followed by mechanical polishing using a diamond solution with particle sizes ranging between 3 and 1 $\mu \mathrm{m}$, followed by electropolishing with 5:3 solution of ethanol $\left(\mathrm{C}_{2} \mathrm{H}_{5} \mathrm{OH}\right)$ and phosphoric acid 
$\left(\mathrm{H}_{3} \mathrm{PO}_{4}\right)$ for $30 \mathrm{~min}$ at $3 \mathrm{~V}$. The grain structure was revealed by subsequent etching at room temperature in an acetic-nital solution $\left(5 \% \mathrm{HNO}_{3}, 15 \%\right.$ acetic acid, $20 \%$ distilled water and $60 \%$ ethanol) for $3 \mathrm{~s}$.

The cross-sections of the corroded samples after $24 \mathrm{~h}$ of immersion were also performed with SEM (FEG SEM SIGMA HD) by vertically mounting the samples in epoxy resin and fixation of the corroded surface by Silver. Element mapping was carried out with EDS (SAMx IDFix) operated at $15 \mathrm{kV}$ to determine the distribution of elements in the corrosion product.

\subsection{X-ray photoelectron spectroscopy measurement}

X-ray photoelectron spectroscopy (XPS) measurements were performed using a KRATOS AXIS Ultra DLD (Kratos Analytical, Manchester, United Kingdom) equipped with a monochromatic $\mathrm{Al} \mathrm{K} \alpha$ anode working at $15 \mathrm{kV}(225 \mathrm{~W})$. For the survey spectra pass energy of $160 \mathrm{eV}$ was used. The investigated area was a region of 700 by $300 \mu \mathrm{m}$ for Mg-0.41Dy alloy while for the Mg-1.43La alloy a spot of $110 \mu \mathrm{m}$ diameter was used. Ar etching was performed for $120 \mathrm{sec}$ with an etching rate of $10 \mathrm{~nm} /$ min related to $\mathrm{Ta}_{2} \mathrm{O}_{5}$ (acceleration voltage $3.8 \mathrm{kV}$ with an extraction current of $160 \mu \mathrm{A})$. For all of the samples, charge neutralization was necessary. The evaluation and validation of the data were carried out with the software CASA-XPS version 2.3.19. Calibration of the spectra was done by adjusting the $\mathrm{C} 1 \mathrm{~s}$ signal to $284.8 \mathrm{eV}$.

\subsection{X-ray diffraction analysis}

The X-ray diffraction (XRD) measurements were performed on Rigaku SmartLab diffractometer equipped with $9 \mathrm{~kW}$ copper rotating anode X-ray source (CuKa radiation $\lambda=0.15418 \mathrm{~nm}$ ), parabolic multilayer mirror in the primary beam, a set of axial divergence eliminating soller slits in both incident and diffracted beam (acceptance $5^{\circ}$ ), a parallel beam soller slit collimator (acceptance $0.5^{\circ}$ ) and HighPix-3000 2D hybrid pixel single photon counting detector in the diffracted beam. Constant incidence angle of the primary beam $\omega=0.6^{\circ}$ was used for the measurement.

\section{Results}

\subsection{Initial microstructures}

Figure 1 shows the SEM micrographs in the backscattering mode with low and high resolution of the as-cast $\mathrm{Mg}-0.3 \mathrm{Ce}, \mathrm{Mg}-0.41 \mathrm{Dy}, \mathrm{Mg}-0.63 \mathrm{Gd}, \mathrm{Mg}-1.44 \mathrm{Nd}$ and $\mathrm{Mg}-1.43 \mathrm{La}$ alloys, respectively. Table 1 summarized the EDS analysis (in wt.\%) in several positions 
(points 1-12) in the microstructures of the as-cast $\mathrm{Mg}-\mathrm{RE}$ alloys. The as-cast microstructure of $\mathrm{Mg}-0.3 \mathrm{Ce}$ alloy exhibits a bimodal grain size distribution with an average grain size of 70 $\mu \mathrm{m}$. The higher magnitude of the SEM micrograph (Figure 1b) demonstrated that the Mg$0.3 \mathrm{Ce}$ contains very small circular particles located within the grain and along the grain boundaries. Table 1 shows that these particles (point 2) contain around 9\% of Ce and their volume fraction was estimated around $8.5 \%$ by measuring the area fraction of the particles in the SEM micrographs.

The Mg-0.41Dy and Mg-0.63Gd alloys exhibit almost similar an elongated granular microstructure with an approximately large grain size of $400 \mu \mathrm{m}$ and the presence of second phases. Both alloys contain twins as shown by arrows. The presence of twins is mostly caused by the mechanical preparation of the samples. The second phases were identified as the $\mathrm{Mg}_{41} \mathrm{Dy}_{5}$ (point 4) with a small volume fraction of $0.4 \%$ and the $\mathrm{Mg}_{12} \mathrm{Gd}$ (point 6) with a volume fraction of $3 \%$, respectively. The size of the $\mathrm{Mg}_{41} \mathrm{Dy} 5$ phase seems to be smaller than $\mathrm{Mg}_{12} \mathrm{Gd}$ phase and homogeneously distributed in the microstructure of Mg-0.41Dy alloy. In contrast, the microstructure of $\mathrm{Mg}-1.44 \mathrm{Nd}$ alloy shows the presence of three different types of second phases. First, circular dark particles identified as $\mathrm{Mg}_{12} \mathrm{Nd}$ (point 8) and the second one are small white particles identified as $\mathrm{Mg}_{41} \mathrm{Nd}_{5}$ (point 9). The third types of particles have elongated rod shape and contain around $20 \%$ of $\mathrm{Nd}$ element (point 10) which could be identified as $\mathrm{Mg}_{24} \mathrm{Nd}$. The later second phase was not reported in the literature and may be formed during the as-cast processing. The volume fraction of these phases was calculated to be around $6 \%$. The $\mathrm{Mg}-1.43 \mathrm{La}$ alloy exhibits a totally different microstructure compared to the other Mg-RE alloys where it is characterised by a dendritic morphology. As shown in Figure 1i, the second phase identified as $\mathrm{Mg}_{12} \mathrm{La}$ phase (point 12) is located at grain boundaries and triple junctions. Previously, based on the XRD measurement this second phase was identified as $\mathrm{Mg}_{17} \mathrm{La} 2$ phase [31]. However, the EDS analysis (point 12) shows clearly that this second phase belongs to the $\mathrm{Mg}_{12} \mathrm{La}$ phase. Obviously, the $\mathrm{Mg}-1.43 \mathrm{La}$ alloy shows the highest fraction of the second phase with a value of $40 \%$.

\subsection{Electrochemical tests}

Figure 2 shows the potentiodynamic polarization curves after $2 \mathrm{~h}$ of immersion in a $3.5 \%$ $\mathrm{NaCl}$ solution for the $\mathrm{Mg}-0.3 \mathrm{Ce}, \mathrm{Mg}-0.41 \mathrm{Dy}, \mathrm{Mg}-0.63 \mathrm{Gd}, \mathrm{Mg}-1.44 \mathrm{Nd}$ and $\mathrm{Mg}-1.43 \mathrm{La}$ alloys, respectively. As can be seen, all alloys exhibit similar trends where the anodic and cathodic branches are not symmetrical. Usually, the anodic branches in the polarization curve represent 
the anodic dissolution of $\mathrm{Mg}$ metal, while the cathodic branches represent the cathodic hydrogen evolution reaction [32]. The anodic part of the polarization curve coincides for all alloys. In the cathodic region, the Mg-1.43La alloy seems to have the highest current density followed by $\mathrm{Mg}-1.44 \mathrm{Nd}$ alloy, while, the $\mathrm{Mg}-0.3 \mathrm{Ce}, \mathrm{Mg}-0.63 \mathrm{Gd}$ and $\mathrm{Mg}-0.41 \mathrm{Dy}$ alloys seem to have a similar current density. These results agree well with the fact that the corrosion process in Mg-based alloys is catholically controlled [33]. The corrosion potential, $\left(E_{\text {corr }}\right)$ and the corrosion current density $\left(I_{\text {corr }}\right)$ values obtained from the curve fitting are listed in Table 2 . Moreover, the polarization resistance $\left(R_{p}\right)$ of different $\mathrm{Mg}-\mathrm{RE}$ alloys represented in Table 2 was calculated from $I_{\text {corr }}$ according to the Stern-Geary equation [34] :

$$
R_{p}=\frac{\beta_{a}\left|\beta_{c}\right|}{2.303\left(\beta_{a}+\left|\beta_{c}\right|\right) I_{c o r r}}
$$

where $\beta_{a}$ and $\beta_{c}$ are the anodic and cathodic slopes, respectively.

As can be revealed from Table 2, the corrosion potential $E_{\text {corr }}$ of Mg-RE alloys is shifted towards negative value in the order of $\mathrm{Mg}-0.41 \mathrm{Dy}<\mathrm{Mg}-0.63 \mathrm{Gd}<\mathrm{Mg}-0.3 \mathrm{Ce}<\mathrm{Mg}-1.44 \mathrm{Nd}<$ $\mathrm{Mg}-1.43 \mathrm{La}$. The corrosion current density, $I_{\text {corr }}$ of $\mathrm{Mg}$-RE alloys increase in the same order than the $E_{\text {corr }}$.

The Nyquist plots obtained from the electrochemical impedance spectroscopy (EIS) for the Mg-0.3Ce, Mg-0.41Dy, Mg-0.63Gd, Mg-1.44Nd and Mg-1.43La alloys in a $3.5 \% \mathrm{NaCl}$ solution are shown in Figure 3. For more visibility, the Nyquist plot of $\mathrm{Mg}-1.43 \mathrm{La}$ alloy is inserted at the upper right with a small scale. The Nyquist plots exhibit three different shapes as a function of the RE alloying elements indicating a different corrosion mechanism in each Mg-RE alloys. First, the Nyquist plot of Mg-0.41Dy alloy shows two capacitive loops: one capacitive loop at the high-frequency region and the second loop located at the medium frequency region. Second, the $\mathrm{Mg}-0.3 \mathrm{Ce}, \mathrm{Mg}-0.63 \mathrm{Gd}$ and $\mathrm{Mg}-1.44 \mathrm{Nd}$ alloys have a similar shape with two capacitive loops at the high and medium frequency region, respectively and an inductive loop in the low-frequency region. Third, the Nyquist plot of Mg-1.43La alloy exhibits one capacitive loop at the high-frequency region and two inductive loops in the low and medium frequency regions. However, it seems that the Mg-1.43 La alloy may exhibit a very small loop almost indistinguishable at the high-frequency region. Such small capacitive loop has been already reported for several Mg-based alloys [35, 36]. The disappearance of the capacitive loop may be attributed to the high corrosion rate of the $\mathrm{Mg}-1.43 \mathrm{La}$ alloy with small corrosion products on the surface of the sample.

Accordingly, the capacitive loop observed at the high-frequency region resulted from both a charge transfer reaction between the metal interface and the solution and also the formation of 
a double layer [37]. The capacitive loop observed at the medium-frequency was attributed to the growth of the corrosion product layer and its resistance. It has been suggested that the medium-frequency capacitive loop represents the combination of pseudo resistance and capacitance of the film formation and dissolution process [38]. The inductive loop suggests the occurrence of pitting corrosion, dissolution of the protective film, the occurrence of relaxation processes of adsorbed species such as $\mathrm{Mg}(\mathrm{OH})^{\text {tads }}$ and the existence of metastable $\mathrm{Mg}^{+}$ion during the dissolution of $\mathrm{Mg}$-based alloy [39]. In fact, the presence of the inductive loop is frankly observed in the Nyquist plots of various Mg-based alloys [40].

As can be seen from Figure 3, the dimension of both capacitive loops in Mg-0.41Dy alloy was higher in comparison to the other Mg-RE alloys indicating a better corrosion resistance of Mg-0.41Dy alloy. It can also be seen that the dimension of medium capacitive loops shrinks with $R E$ elements as $\mathrm{Mg}-0.3 \mathrm{Ce}, \mathrm{Mg}-0.63 \mathrm{Gd}, \mathrm{Mg}-1.44 \mathrm{Nd}$ and $\mathrm{Mg}-1.43 \mathrm{La}$ alloys reflecting the heterogeneity of the corrosion products and their less protective effect.

The corresponding equivalent electrical circuit and the fitted data of the Nyquist curves are presented in Figure 4 and Table 4, respectively. Using a simulated equivalent circuit can usually help to explain the general corrosion process. $R_{s}, R_{c t}, R_{f}$ and $R_{L}$ are the solution resistance, charge transfer resistance, film resistance and inductance resistance, respectively. $C P E_{d l}$ and $C P E_{f}$ are constant phase elements representing the capacitance in the high and medium frequencies region, respectively. The CPE is defined by two values, $Y$ and $n$ and usually employed instead of the capacitance in case of the non-homogeneity of the sample surface [41]. If $n=1, C P E$ will be identical to a capacitor.

All the Mg-RE alloys have almost the same value of $R_{s}$ demonstrating that $\mathrm{RE}$ alloying elements have similar behaviour in the contact with the $3.5 \% \mathrm{NaCl}$ solution. Nevertheless, the $R_{s}$ value is more sensitive to the concentration of $\mathrm{Cl}^{-}$ions [42].

The double-layer capacitance $Y_{d l}$ value is generally found in the range of $50-100 \mu \mathrm{F} \mathrm{cm} \mathrm{cm}^{-2}$ [43]. It is interesting to note that the $Y_{d l}$ values of the present $\mathrm{Mg}$-RE alloys are lower compared to the literature and vary slightly as a function of RE alloying elements. Usually, double-layer capacitance increases with the decrease of the surface of the protective film [44]. Moreover, the value of $n_{d l}$ is close to being similar, indicating that the capacitive loop is welldefined, except in case of the Mg-1.43La alloy where $n_{d l}=0.79$.

The resistance value $R_{c t}$ indicates the dissolution rate of $\mathrm{Mg}$ metal. The smaller corrosion rate is obtained the higher $R_{c t}$ is. Accordally, the $R_{c t}$ increases as $\mathrm{Mg}-1.43 \mathrm{La}<\mathrm{Mg}-1.44 \mathrm{Nd}<\mathrm{Mg}-$ $0.63 \mathrm{Gd}<\mathrm{Mg}-0.3 \mathrm{Ce}<\mathrm{Mg}-0.41 \mathrm{Dy}$, which indicates that the corrosion rate is lower in $\mathrm{Mg}-$ $0.41 \mathrm{Dy}$ alloy and higher in $\mathrm{Mg}-1.43 \mathrm{La}$ alloy. 
The $Y_{f}$ values of the corrosion product capacity were found much higher than those of $Y_{d l}$ (double layer capacity), except for $\mathrm{Mg}-1.43 \mathrm{La}$ alloy which was in the same order of magnitude $\left(Y_{d l}=5.16 \times 10^{-5}\right.$ vs. $\left.Y_{f}=2.38 \times 10^{-5} \mathrm{~F} \mathrm{~cm}^{-2}\right)$. This is in good agreement with the assumption that the surface covered by the corrosion products is large compared to the free area of the surface [43].

The inductance in the equivalent circuit of $\mathrm{Mg}-0.3 \mathrm{Ce}, \mathrm{Mg}-0.63 \mathrm{Gd}$ and $\mathrm{Mg}-1.44 \mathrm{Nd}$ alloys shows high values (in range of 5586 to $15876 \mathrm{H} . \mathrm{cm}^{-2}$ ) while the value in the case of the Mg-

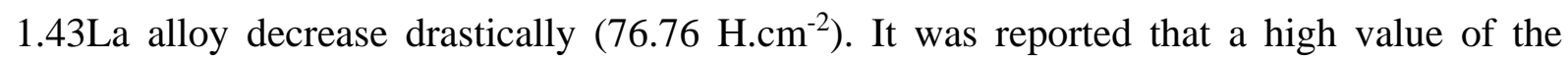
inductance indicates relative uniform corrosion in the surface of the sample [27].

\subsection{Corrosion morphology}

Based on the electrochemical tests, the Mg-0.41Dy and Mg-1.43La alloys show the best and worst corrosion resistance, respectively. Following, the characterization of the corrosion morphology for those alloys will be taken into account.

Figure 5 shows the photographs of the surface of $\mathrm{Mg}-0.41 \mathrm{Dy}$ and $\mathrm{Mg}-1.43 \mathrm{La}$ alloys after $2 \mathrm{~h}$ and $24 \mathrm{~h}$ of immersion in $3.5 \% \mathrm{NaCl}$ solution, respectively. As can be seen, the surface of Mg-0.41Dy alloy was slightly affected by the extension of immersion time. Small grey spots appeared on the surface of the Mg-0.41Dy alloy after $24 \mathrm{~h}$ of immersion. Meanwhile, the surface of the Mg-1.43La exhibits severe corrosion after $24 \mathrm{~h}$ of immersion in $3.5 \% \mathrm{NaCl}$ solution. At the beginning (after $2 \mathrm{~h}$ of immersion) the corrosion started from one edge of the sample (zone with grey colour) by the presence of small white spots on the surface of the Mg1.43La sample and with ongoing time a dense rough surface formed by a white-grey layer grows until $24 \mathrm{~h}$ of immersion.

Figure 6 shows the surfaces in the cross-section of the Mg-0.41Dy and Mg-1.43La alloys obtained by optical microscopy after immersion for $24 \mathrm{~h}$ in $3.5 \% \mathrm{NaCl}$ solution, respectively. It can be seen that the corrosion layer morphology of the Mg-0.41Dy alloy is thin and uniform. In contrast, the corroded surface of the $\mathrm{Mg}-1.43 \mathrm{La}$ alloy is very thick and exhibits several localized corrosion sites as shown by arrows.

The SEM micrographs by backscattering mode presented in Figure 7 and 8 with low and high resolution show the microscopic corrosion morphologies of the $\mathrm{Mg}-0.41 \mathrm{Dy}$ and $\mathrm{Mg}-1.44 \mathrm{La}$ alloys after $2 \mathrm{~h}$ and $24 \mathrm{~h}$ immersion in $3.5 \% \mathrm{NaCl}$ solution, respectively.

Figure 7a shows that the morphology of the surface of the Mg-0.41Dy alloy after $2 \mathrm{~h}$ of immersion was uniform and smooth and some cracks can be noticed on the surface of the 
alloy after $24 \mathrm{~h}$ of immersion (Figure 7c). The presence of cracks is caused by the dehydration of the corrosion product. Increasing the resolution of the SEM images of the corroded surfaces as shown in Figure $7 \mathrm{~b}$ and $7 \mathrm{~d}$ indicate that the alloy exhibits typical corrosion morphology of needle-like particles. No significant difference in the morphology of the surface of Mg-0.41Dy alloy after $24 \mathrm{~h}$ of immersion, except that the needle got thinker. It has been suggested that the small and dense needle-like particles are more protective [45].

The corrosion morphology of the $\mathrm{Mg}-1.43 \mathrm{La}$ alloy after immersion for $2 \mathrm{~h}$ is relatively similar to those of the Mg-0.41Dy alloy. In can see from Figure 8a that the $\mathrm{Mg}_{12} \mathrm{La}$ phase is visible along the grain boundaries (shown by arrows) mostly due to the attack effect from the $3.5 \% \mathrm{NaCl}$ solution. This observation may indicate that the $\mathrm{Mg}-1.43 \mathrm{La}$ alloy is corroded by an intergranular corrosion type. Besides, the volume fraction of the $\mathrm{Mg}_{12} \mathrm{La}$ phase seems to decrease after immersion for $2 \mathrm{~h}$. In the higher resolution, the $\mathrm{Mg}_{12} \mathrm{La}$ phase seems to be covered by the same needle-like particles as the $\mathrm{Mg}$ matrix (dashed line in Figure $8 \mathrm{~b}$ ). The needle-like particles are larger and less compact than to those on the Mg matrix. The surface of the $\mathrm{Mg}-1.43 \mathrm{La}$ alloy after immersion for $24 \mathrm{~h}$ is covered by a thick and irregular film of corrosion products which is completely different from the Mg-0.41Dy alloy.

Figure 7 and 8 show also the presence of few mushrooms like shaped precipitations formed on the surface of both alloys expect for Mg-1.43La after $24 \mathrm{~h}$ of immersion. The absence of these agglomerations in the immersed $\mathrm{Mg}-1.43 \mathrm{La}$ alloy up $24 \mathrm{~h}$ is attributed the severely corroded surface. It can be seen that these agglomerations are bigger in the Mg-1.43La alloy. A close up is presented in Figure 9 showing the micrograph of these mushrooms like shaped precipitations on the surface of the Mg-0.41Dy alloy after immersion for $24 \mathrm{~h}$. The corresponding EDS analysis of point 1, 2 and 3 areas are presented in Table 4. Obviously, these particles (point 1) and around them (point 2) contain a high fraction of $\mathrm{Cl}$. The surface of the point 3 revealed the presence of the magnesium hydroxide $\operatorname{Mg}(\mathrm{OH})_{2}$ compound which is a typical corrosion product largely reported for Mg-based alloys in aqueous solutions [46]. The evolution of $\mathrm{pH}$ value as a function of immersion time of both alloys shown in the upper right side of Figures $7(\mathrm{a}, \mathrm{c})$ and Figures $8(\mathrm{a}, \mathrm{c})$ indicate clearly that the corrosion processing in the $\mathrm{Mg}-0.41 \mathrm{Dy}$ and $\mathrm{Mg}-1.43 \mathrm{La}$ alloys is totally different. It is to be noted that the initial $\mathrm{pH}$ value of the $3.5 \% \mathrm{NaCl}$ solution was measured to be 6.55 . The $\mathrm{pH}$ value of the $\mathrm{Mg}-0.41 \mathrm{Dy}$ alloy increases slightly after immersion for $2 \mathrm{~h}$ and then reach a value of 8.4 after $24 \mathrm{~h}$ of immersion. In contrast, the $\mathrm{pH}$ value for the $\mathrm{Mg}-1.43 \mathrm{La}$ alloy increases rapidly to 10.3 after immersion for $24 \mathrm{~h}$. 
To get more detailed information of the corrosion product composition, XPS and XRD analysis were performed for the Mg-0.41Dy and $\mathrm{Mg}-1.43 \mathrm{La}$ alloys after $2 \mathrm{~h}$ and $24 \mathrm{~h}$ of immersion in $3.5 \% \mathrm{NaCl}$ solution (Figures 10 and 11). The XPS survey spectra for all samples revealed the presence of $\mathrm{Mg}, \mathrm{O}, \mathrm{C}$ and $\mathrm{Cl}$ at the very surface. So, the outer corrosion layer consists mainly from the $\mathrm{MgCO}_{3}$ and $\mathrm{MgO} / \mathrm{Mg}(\mathrm{OH})_{2}$ with some enrichment of $\mathrm{Cl}$ that is caused either by the $3.5 \% \mathrm{NaCl}$ solution (remaining $\mathrm{Cl}$ ) or by the $\mathrm{MgCl}_{2}$ as a reaction product. The concentrations of the different elements seem to be stable with increasing immersion time for both alloys as shown in Table 5. In contrast, neither Dy nor La can be found on the outer layer of the corroded surfaces. First, this is can be attributed to the low concentration of the alloying element in the $\mathrm{Mg}$ matrix $(0.41 \%$ Dy and $1.43 \% \mathrm{La})$. Furthermore, it might be that corrosion product consisting of Dy of La will not be present in the very first 3-5 nm, which is the investigation limit of the XPS method while XRD penetrates more the bulk material.

Figure 11 shows the XRD patterns of as-cast material as well as after immersion for $2 \mathrm{~h}$ and 24 $\mathrm{h}$ in $3.5 \% \mathrm{NaCl}$ of $\mathrm{Mg}-0.41 \mathrm{Dy}$ and $\mathrm{Mg}-1.43 \mathrm{La}$ alloys, respectively. The XRD patterns of both as-cast alloys confirm the presence of the $\mathrm{Mg}_{24} \mathrm{Dy}_{5}$ and $\mathrm{Mg}_{12} \mathrm{La}$ phases as already demonstrated by the SEM-EDS analysis in Figure 1. Immersion in $3.5 \% \mathrm{NaCl}$ for $2 \mathrm{~h}$ leads to the development of news peaks identified as the corrosion product $\mathrm{Mg}(\mathrm{OH})_{2}$ in both alloys. Contrary to the Mg-1.43La alloy, the second phase was not detected in the Mg-0.41Dy alloy. Such difference could be attributed to the total covering of the surface by the corrosion product in Mg-0.41Dy alloy. An interesting feature can be seen after immersion of $24 \mathrm{~h}$. Besides the presence of the corrosion product $\mathrm{Mg}(\mathrm{OH})_{2}$ a new oxide $\mathrm{Dy}_{2} \mathrm{O}_{3}$ is formed on the Mg-0.41Dy surface. In the meantime, the XRD pattern of $\mathrm{Mg}-1.43 \mathrm{La}$ shows the disappearance of the $\mathrm{Mg}$ matrix peaks and the appearance of small peaks belonging to the $\mathrm{MgCl}_{2}$ phase.

\section{Discussion}

The kinetics of the corrosion process in various Mg-based alloys in aqueous solution are generally expressed by the following equations [46]:

Anodic reaction: $\quad \mathrm{Mg} \rightarrow \mathrm{Mg}^{2+}+2 \mathrm{e}^{-}$

Cathodic reaction: $\quad \mathrm{H}_{2} \mathrm{O}+2 \mathrm{e}^{-} \rightarrow 2 \mathrm{OH}^{-}+\mathrm{H}_{2}$

The corrosion reaction leads to the formation of $\mathrm{Mg}(\mathrm{OH})_{2}$ accompanied by hydrogen evolution: 
The total reaction: $\quad \mathrm{Mg}+\mathrm{H}_{2} \mathrm{O} \rightarrow \mathrm{Mg}(\mathrm{OH})_{2}+\mathrm{H}_{2}$

It was expected that $\mathrm{Mg}$ alloys containing $R E$ elements will have similar corrosion behaviour; however, the electrochemical measurements plotted in Figures 2 and 3 show clearly that the present $\mathrm{Mg}-0.3 \mathrm{Ce}, \mathrm{Mg}-0.41 \mathrm{Dy}, \mathrm{Mg}-0.63 \mathrm{Gd}, \mathrm{Mg}-1.44 \mathrm{Nd}$ and $\mathrm{Mg}-1.43 \mathrm{La}$ alloys exhibit relative different rate response of the cathodic kinetics and different corrosion mechanism as well. The corrosion rate of binary $\mathrm{Mg}-\mathrm{Y}$ and $\mathrm{Mg}-\mathrm{Nd}$ alloys in a similar $0.1 \mathrm{M} \mathrm{NaCl}$ solution ( $\mathrm{pH} \sim 6.1$ ) was also found totally different $[30,47]$. The present results indicate that the $\mathrm{Mg}-$ $0.41 \mathrm{Dy}$ alloy has the better corrosion resistance $\left(5.58 \mathrm{Ohm} . \mathrm{cm}^{2}\right)$ and the $\mathrm{Mg}-1.43 \mathrm{La}$ alloy the lower one $\left(2.89 \mathrm{Ohm} . \mathrm{cm}^{2}\right)$. It is interesting to note that for the Mg-0.41Dy alloy a more noble (i.e. Ecorr shift toward 0 value) was found compared with several $\mathrm{Mg}$-based alloys such as Mg-Al-Mn [48], AZ31 [9, 49], AZ91[11] and pure Mg [50] immersed in 3.5\% NaCl solution. The electrochemical investigations demonstrated that the present $\mathrm{Mg}-\mathrm{RE}$ alloys exhibit three different corrosion mechanisms. 1) The presence of only two capacitive loops in the Mg0.41Dy alloy corresponds to uniform corrosion mechanism, i.e. the alloy surface was completely covered by the corrosion product film. This is confirmed by the very good corrosion surface of the Mg-0.41Dy alloy even after immersion for $24 \mathrm{~h}$ in $3.5 \% \mathrm{NaCl}$ solution (Figures 5 and 6), except maybe the presence of few mushrooms like shaped precipitations (Figure 8). However, these agglomerations do not cause pitting corrosion since no induction loop was seen in the Nyquist plot of the alloy. 2) The second corrosion mechanism is characterized by the addition of the inductive loop in the Nyquist plot in the case of $\mathrm{Mg}-0.3 \mathrm{Ce}, \mathrm{Mg}-0.63 \mathrm{Gd}$ and $\mathrm{Mg}-1.44 \mathrm{Nd}$ alloys. It indicates a heterogeneous corrosion mechanism [27]. The similarity in the shapes of the Nyquist plots for $\mathrm{Mg}-0.3 \mathrm{Ce}, \mathrm{Mg}-0.63 \mathrm{Gd}$ and $\mathrm{Mg}-1.44 \mathrm{Nd}$ alloys suggest that the $\mathrm{Ce}, \mathrm{Gd}$ and $\mathrm{Nd}$ elements have no effect on the mechanism of the formation but affect considerably the properties of corrosion products. As shown in Table 4, the corrosion resistance of the protective product $R_{f}$ was estimated at 2749 $\Omega . \mathrm{cm}^{2}$ in the Mg-0.3Ce alloy and decrease to 1993 and $769.9 \Omega . \mathrm{cm}^{2}$ in $\mathrm{Mg}-0.63 \mathrm{Gd}$ and $\mathrm{Mg}$ $1.44 \mathrm{Nd}$ alloys, respectively. In addition, the decrease of the inductance value with respect to Ce $\left(15876\right.$ H.cm $\left.{ }^{-2}\right), \mathrm{Gd}\left(10228 \mathrm{H} . \mathrm{cm}^{-2}\right)$ and $\mathrm{Nd}\left(5586 \mathrm{H} . \mathrm{cm}^{-2}\right)$ indicated that Nd suffer more from the pitting corrosion than Ce and Gd. 3) The third corrosion mechanism is shown in the Mg-1.43La alloys where the alloy exhibits two inductive loops indicating severe corrosion attacks (as shown by the morphology in the Figures 5, 6 and 8) or micro-galvanic corrosion. The presence of tow inductive loops was already reported for Mg-based alloys [29, 51]. The presence of the second inductive loop is caused by the extra $\mathrm{Mg}$ dissolution due to the 
reaction of $\mathrm{Mg}^{+}$with $\mathrm{H}_{2} \mathrm{O}$ in the non-protective area of the surface following the non-Faraday process $[29,51]$ :

$$
2 \mathrm{Mg}^{+}+2 \mathrm{H}_{2} \mathrm{O} \rightarrow 2 \mathrm{Mg}^{2+}+2 \mathrm{OH}^{-}+\mathrm{H}_{2}
$$

The release of hydroxide ions $\left(\mathrm{OH}^{-}\right)$leads to the highest increase in $\mathrm{pH}$ value of the $\mathrm{Mg}$ 1.43La alloy compared to the Mg-0.41Dy as reported for Figures 7 and 8.

The result of EIS is in good agreement with the polarization curve analyses. It can be seen that the Mg-0.41Dy alloy exhibits the higher $R_{f}$ value $\left(3568 \Omega . \mathrm{cm}^{2}\right)$ and $\mathrm{Mg}-1.43 \mathrm{La}$ alloy the lower value (429.1 $\left.\Omega . \mathrm{cm}^{2}\right)$. The $R_{f}$ values of different Mg-RE alloys shown in Table 4 that the corrosion product formed at the surface of $\mathrm{Mg}-0.41 \mathrm{Dy}$ alloy has a better capacity to protect the alloy against metal dissolution. It was found that among the $\mathrm{RE}(\mathrm{Y}, \mathrm{Nd} \mathrm{Gd}$ and $\mathrm{Dy}$ ) metals, the Dy metal exhibits the best corrosion resistance in $0.1 \mathrm{~mol} / \mathrm{L} \mathrm{NaCl}$ solution [52].

The difference in the corrosion mechanism in the present $\mathrm{Mg}-\mathrm{RE}$ alloys is strongly related to two major factors. The first factor is the effect of the specific $R E$ elements added in the $\mathrm{Mg}$ matrix. The second one is the specific microstructure of the alloys, i.e. the presence of second phase, grain size.

\subsection{Effect of specific RE alloying element}

The rare earth elements are usually divided into two subgroups: the cerium subgroup which includes $\mathrm{La}, \mathrm{Ce}, \mathrm{Nd}, \mathrm{Pm}, \mathrm{Sm}$ and $\mathrm{Eu}$ and the yttrium subgroup which contain the remaining $R E$ elements such as Gd and Dy [53]. This subdivision is based on the differences and similarities in the properties of the different $R E$ elements. The change in the physicochemical properties between the different $R E$ elements is observed with a successive increase of the RE metal atomic number and it is more related to the electron configuration of each specific element [53]. Table 6 summarized some specific features of the $R E$ elements used in the present study. It was reported that the $R E$ elements could show similar chemical properties when the energy levels of the $4 f$ and $5 d$ in the atoms are close [53]. Based on that, Table 5 shows that the Ce, Dy, Gd, Nd elements exhibit different properties. For example, among the used $R E$ elements, La is considered the only transition metal as demonstrated by the configuration of the outer electronic shells $\left(5 d^{1} 6 s^{2}\right)$ and the Dy element is the most stable as shown by the complete filled $4 f$ shell. The electronegativity values of the $R E$ elements were close to the electronegativity of $\mathrm{Mg}$ (1.2) [53]. However, La presents the highest electronegativity difference which suggests that the formed compounds between $\mathrm{Mg}$ and $\mathrm{La}$ are more stable than the other $R E$ elements. 
The density of $R E$ elements is an important physical characteristic for the formed Mg-RE alloys. Table 6 shows that the density of the present $R E$ elements increases with the increasing atomic number. Interestingly the corrosion resistance was found to increase with increasing atomic number of $R E$ elements, expect for Ce element showing higher corrosion resistance than $\mathrm{Gd}$ and $\mathrm{Nd}$ elements. This anomaly could be attributed to the difference in the microstructures between the alloys as shown in Figure 1, which leads us to discuss the second factor.

\subsection{Effect of the microstructure on the corrosion behavior}

Contrary to the other binary alloys, the $\mathrm{Mg}-0.3 \mathrm{Ce}$ alloy has the smallest grain size $(\sim 70 \mu \mathrm{m})$. It was reported that the grain boundaries can act as barriers for corrosion in Mg-based alloys [54]. Theoretically, a microstructure with small grain size involves a high number of grain boundaries which result in more improvement of the corrosion resistance in case of the $\mathrm{Mg}$ $0.3 \mathrm{Ce}$ alloy. On the other hand, the diversity of the second phase $\left(\mathrm{Mg}_{12} \mathrm{Nd}, \mathrm{Mg}_{41} \mathrm{Nd}_{5}\right.$ and $\mathrm{Mg}_{24} \mathrm{Nd}$ ) is the reason of the poor corrosion of the $\mathrm{Mg}-1.44 \mathrm{Nd}$ alloy compare to the $\mathrm{Mg}-0.3 \mathrm{Ce}$ and $\mathrm{Mg}-0.63 \mathrm{Gd}$ (the group with the same corrosion mechanism) by providing more cathodic phases and causing more dissolution of the $\mathrm{Mg}$ matrix.

Dy and Gd are more distributed into the Mg matrix since their solubility in the $\mathrm{Mg}$ matrix, $25.23 \%$ and $23.49 \%$, respectively are much higher than that of $\mathrm{Ce}(0.23 \%), \mathrm{Nd}(3.6 \%)$ or $\mathrm{La}$ $(0.74 \%)$ [55]. Therefore it is expected that the potential difference between the $\mathrm{Mg}$ matrix and the second phase will be small which will reduce the microgalvanic corrosion.

It is important to note, that the present $\mathrm{Mg}-\mathrm{RE}$ alloys were used in the as-cast condition where the resulted microstructures were rather irregular (Figure 1). The $\mathrm{Mg}_{41} \mathrm{Dy}_{2}$ phase is considered metastable since the Mg-Dy phase diagram [56] shows that the Mg-0.41Dy alloys is $(0.41 \%$ of Dy) is a solid solution. It is expected that the metastable phase will have less effect against corrosion than the stable one such as $\mathrm{Mg}_{12} \mathrm{La}$ phase in case of the $\mathrm{Mg}-1.43 \mathrm{La}$ alloy. Besides, the results of the micro-capillary electrochemical cell method on $\mathrm{Mg}_{12} \mathrm{Ce}, \mathrm{Mg}_{3} \mathrm{Nd}$ and $\mathrm{Mg}_{12} \mathrm{La}$ second phases show that the $\mathrm{Mg}_{12} \mathrm{La}$ phase is the less inert compared to the other second phases [30].

The amounts of second phases in the microstructure have a great influence on corrosion behaviour. Figure 1 demonstrated that $\mathrm{Mg}$-1.43La alloy exhibits a high fraction of second phase $(40 \%)$ and the $\mathrm{Mg}-0.41 \mathrm{Dy}$ alloy the lower one $(0.4 \%)$. It was reported that the corrosion resistance decreases with the increasing amount of $\mathrm{Y}$ in binary $\mathrm{Mg}-\mathrm{Y}$ alloy due to the increase of volume fraction of the intermetallic $\mathrm{Mg}_{24} \mathrm{Y}_{5}$ phase [47]. Also, the XRD 
patterns (Figure 10) and SEM micrograph (Figure 7a) show the presence of the $\mathrm{Mg}_{12} \mathrm{La}$ phase in $\mathrm{Mg}$-1.43La alloy even after $2 \mathrm{~h}$ of immersion. Obviously, the immersion for $2 \mathrm{~h}$ causes the dissolution of the $\mathrm{Mg}_{12} \mathrm{La}$ phase as shown by the decrease of their volume fraction which suggests that this phase is preferentially corroded than the Mg matrix by acting as the anodic phase.

It is well established that the second phases are nobler than the $\mathrm{Mg}$ matrix and act as a cathodic phase in the corrosion process of traditional Mg-based alloys such as AZ91 $(\mathrm{Mg}$ 9Al-1Zn, wt\%) alloy which explains the acceleration of the dissolution of the Mg matrix and the corrosion rate of $\mathrm{Mg}$-based alloys [36]. However, because $R E$ elements are more active than $\mathrm{Mg}$, it was demonstrated recently that the second phases in $\mathrm{Mg}-\mathrm{RE}$ based alloys preferentially dissolved at the initial corrosion stage by acting as micro-anodes, which is completely different from the role of second phases in traditional Mg-based alloys [57-59].

For more comparison, the morphology of the corrosion product in the cross-sections of $\mathrm{Mg}$ $0.41 \mathrm{Dy}$ and $\mathrm{Mg}-1.43 \mathrm{La}$ alloys after $24 \mathrm{~h}$ of immersion in $3.5 \% \mathrm{NaCl}$ solution are presented by the SEM images and chemical element mapping in Figure 12 and 13, respectively. The Mg0.41Dy exhibits very good corrosion protection with a uniform and flat surface. No pitting and located corrosion were detected in the cross-section of the sample. Meanwhile, some crack could be noticed on the corrosion product. The depth of corrosion product in $\mathrm{Mg}$ $0.41 \mathrm{Dy}$ alloy was measured to be around $7 \mu \mathrm{m}$. The elemental maps on the cross-section of the Mg-0.41Dy alloy shown in Figure 8 demonstrated that the chemical composition of the corrosion layer consists mostly of both hydroxides $\mathrm{Mg}(\mathrm{OH})_{2}$ and/or magnesium oxides $\mathrm{MgO}$. In contrast, it can be observed in Figure 13 that two distinguish corrosion layers are formed on the surface of the $\mathrm{Mg}-1.43 \mathrm{La}$ alloy which is consistent with the higher corrosion rate found by electrochemical tests. The outer corrosion layer ( $38 \mu \mathrm{m}$ of thickness) is non-uniform and porous with high amounts of $\mathrm{O}, \mathrm{Mg}$, and $\mathrm{C}$ elements. Meanwhile, the chemical element mapping demonstrated that besides the presence of $\mathrm{Mg}$ and $\mathrm{O}$ elements the compact inner corrosion layer (with $20 \mu \mathrm{m}$ of thickness) contain also $\mathrm{Cl}$ elements. It can be noticed that the inner corrosion layer exhibits small cracks compared the outer corrosion layer and localized corrosion around $\mathrm{Mg}_{12} \mathrm{La}$ phase. It can be observed that the front of the corrosion attack is consuming the lamellar $\mathrm{Mg}_{12} \mathrm{La}$ phase. The occurrence of localized corrosion and the presence of $\mathrm{Cl}$ in the corrosion product facilitate the penetration of the solution into the underneath of the $\mathrm{Mg}$ metal and then cause the propagation of the pitting corrosion.

The actual result is in very good agreement with the recent proposed pitting corrosion mechanism in Mg-RE alloys [58]. It was reported that corrosion pitting involved three stages. 
Firstly, the anodic phase dissolved followed by the corrosion of the Mg matrix and then the pitting corrosion appeared along with the depth of the dissolved phases [58].

Furthermore, the corrosion products formed on the surfaces of the Mg-0.41Dy and Mg-1.43 alloy are quite different. The XRD patterns demonstrated that the surface of Mg-0.41Dy is covered by the $\mathrm{Dy}_{2} \mathrm{O}_{3}$ oxide; contrary to the $\mathrm{Mg}-1.43$ alloy (Figure 11). The enthalpy of formation of oxide $\mathrm{Dy}_{2} \mathrm{O}_{3}, \Delta H_{f}=-1869 \mathrm{~kJ} /$ mole, suggest that this oxide is chemically more stable than the $\mathrm{La}_{2} \mathrm{O}_{3}$ oxide with the value of $\Delta H_{f}=-1791 \mathrm{~kJ} / \mathrm{mole}$ [60]. Instead of that, the surface of $\mathrm{Mg}-1.43 \mathrm{La}$ shows the presence of $\mathrm{MgCl}_{2}$ phase. The presence of $\mathrm{Cl}$ ions in the solution accelerates the dissolution of the protective film by penetrating in the micro-pores and transforming the $\mathrm{Mg}(\mathrm{OH})_{2}$ into more soluble $\mathrm{MgCl}_{2}$ [61] which cause accumulation of massive corrosion as demonstrated by the Photography of the Mg-1.43La alloy (Figure 5c) and the occurrence of second inductance loop in the Nyquist plot (Figure 3).

Taking into account that the penetration depth of X-ray in SEM is around 20 to $40 \mu \mathrm{m}$ with a huge accelerated volume (depending on the acceleration voltage) while the XPS investigations (shown in Figure 11) which will only give information of the very first 3-5 nm of the surface, information from both methods might be different. This leads to the conclusion that the $\mathrm{Dy}_{2} \mathrm{O}_{3}$ phase should be formed in the inner layer of the corrosion product since the outer layer (3-5 nm) for both alloys was composed mainly of $\mathrm{MgCO}_{3}$ and $\mathrm{MgO} / \mathrm{Mg}(\mathrm{OH})_{2}$. It is to be noted that etching of the sample surface in XPS by Ar ions for $120 \mathrm{sec}$ removed only about 12-16 nm from the surface of the alloy. However, the XPS measurement of both alloys without etching (not shown here) present similar concentration of $\mathrm{Mg}, \mathrm{O}$ and $\mathrm{Cl}$, expect an increase of $\mathrm{C}$ concentration before etching due to the surface contamination by the $\mathrm{CO}_{2}$ adsorption from the environment.

Hence, the present results would offer some useful information for a better understanding of the corrosion behaviour of Mg-RE alloys concerning the RE alloying addition to develop a new generation of Mg-based alloys with excellent corrosion resistance and therefore extend their use in a variety of applications.

\section{Conclusions}

- The corrosion behaviour of Mg-0.41Dy, Mg-0.3Ce, Mg-0.63Gd, Mg-1.44Nd and Mg$1.43 \mathrm{La}$ alloys in $3.5 \% \mathrm{NaCl}$ solution was evaluated by electrochemical tests and morphological observations. 
- The corrosion resistance of Mg-RE alloys increases with RE alloying elements in the following order: $\mathrm{Mg}-1.43 \mathrm{La}, \mathrm{Mg}-1.44 \mathrm{Nd}, \mathrm{Mg}-0.3 \mathrm{Ce}, \mathrm{Mg}-0.63 \mathrm{Gd}$ and $\mathrm{Mg}-0.41 \mathrm{Dy}$.

- A complete protective layer covers the Mg-0.41Dy alloy surface which indicates uniform corrosion mechanism. A partially protective film covers the surface of $\mathrm{Mg}$ 0.3Ce; Mg-1.44Nd and Mg.0.63Gd alloys caused a non-uniform corrosion mechanism. The Mg-1.43La alloy exhibits micro-galvanic corrosion mechanism caused by the pitting corrosion.

- The formation of the $\mathrm{Dy}_{2} \mathrm{O}_{3}$ oxide prevents the $\mathrm{Mg}-0.41 \mathrm{Dy}$ alloy from pitting corrosion and lead to an excellent corrosion surface even after $24 \mathrm{~h}$ of immersion. Meanwhile, the high volume fraction of the $\mathrm{Mg}_{12} \mathrm{La}$ phase and the size of its dendriticshaped are responsible for the severe corrosion of $\mathrm{Mg}-1.43 \mathrm{La}$ alloy.

- The $\mathrm{Mg}_{12} \mathrm{La}$ second phase acts as micro-anode during the corrosion of the $\mathrm{Mg}-1.43 \mathrm{La}$ alloy.

\section{Acknowledgements}

The authors gratefully acknowledge Dr. Talal Al-Samman; Institute für Metallkunde und Metallphysik (IMM-RWTH), Aachen, Germany, for supplying the Mg-RE alloys. This work was supported by the PRFU national project under Grant Agreement No. B00L02UN280120180005. M.D. acknowledges the financial support from the project NanoCent - Nanomaterials Centre for Advanced Applications, Project No. CZ.02.1.01/0.0/0.0/15_003/0000485, financed by ERDF.

\section{Data availability}

The raw/processed data required to reproduce these findings cannot be shared at this time as the data also forms part of an ongoing study.

\section{Funding sources}

This research did not receive any specific grant from funding agencies in the public, commercial, or not-for-profit sectors.

\section{References}


[1] J. Hirsch, T. Al-Samman, Superior light metals by texture engineering: Optimized aluminum and magnesium alloys for automotive applications, Acta Materialia, 61 (2013) 818843. DOI: https://doi.org/10.1016/j.actamat.2012.10.044.

[2] M. Esmaily, J.E. Svensson, S. Fajardo, N. Birbilis, G.S. Frankel, S. Virtanen, R. Arrabal, S. Thomas, L.G. Johansson, Fundamentals and advances in magnesium alloy corrosion, Progress in Materials Science, 89 (2017) 92-193. DOI: https://doi.org/10.1016/j.pmatsci.2017.04.011.

[3] A. Atrens, S. Johnston, Z. Shi, M.S. Dargusch, Viewpoint - Understanding Mg corrosion in the body for biodegradable medical implants, Scripta Materialia, 154 (2018) 92-100. DOI: https://doi.org/10.1016/j.scriptamat.2018.05.021.

[4] R. Udhayan, D.P. Bhatt, On the corrosion behaviour of magnesium and its alloys using electrochemical techniques, Journal of Power Sources, 63 (1996) 103-107. DOI: https://doi.org/10.1016/S0378-7753(96)02456-1.

[5] A. Atrens, G.-L. Song, M. Liu, Z. Shi, F. Cao, M.S. Dargusch, Review of Recent Developments in the Field of Magnesium Corrosion, Advanced Engineering Materials, 17 (2015) 400-453. DOI: https://doi.org/10.1002/adem.201400434.

[6] G. Song, A. Atrens, Understanding Magnesium Corrosion-A Framework for Improved Alloy Performance, Advanced Engineering Materials, 5 (2003) 837-858. DOI: 10.1002/adem.200310405.

[7] T.B. Abbott, Magnesium: Industrial and Research Developments Over the Last 15 Years, CORROSION, 71 (2015) 120-127. DOI: https://doi.org/10.5006/1474.

[8] K.C. Tekin, U. Malayoğlu, S. Shrestha, Electrochemical behavior of plasma electrolytic oxide coatings on rare earth element containing Mg alloys, Surface and Coatings Technology, 236 (2013) 540-549. DOI: https://doi.org/10.1016/j.surfcoat.2013.10.051.

[9] D. Zhang, Y. Gou, Y. Liu, X. Guo, A composite anodizing coating containing superfine Al2O3 particles on AZ31 magnesium alloy, Surface and Coatings Technology, 236 (2013) 52-57. DOI: https://doi.org/10.1016/j.surfcoat.2013.04.059.

[10] S. Jafari, R.K. Singh Raman, In-vitro biodegradation and corrosion-assisted cracking of a coated magnesium alloy in modified-simulated body fluid, Materials science \& engineering. C, Materials for biological applications, 78 (2017) 278-287. DOI: 10.1016/j.msec.2017.04.079.

[11] B. Han, D. Gu, Q. He, X. Zhang, G. Peng, C. Yang, Fabrication of a novel Mg-RE $(\mathrm{Nd}, \mathrm{Ce})$ intermetallic compound coating by molten salt diffusion and its effect on corrosion 
resistance of magnesium alloys, Journal of Rare Earths, 34 (2016) 731-735. DOI: https://doi.org/10.1016/S1002-0721(16)60084-4.

[12] R.F. Zhang, S.F. Zhang, Formation of micro-arc oxidation coatings on AZ91HP magnesium alloys, Corrosion Science, 51 (2009) 2820-2825. DOI: https://doi.org/10.1016/j.corsci.2009.08.009.

[13] J. Liang, P.B. Srinivasan, C. Blawert, M. Störmer, W. Dietzel, Electrochemical corrosion behaviour of plasma electrolytic oxidation coatings on AM50 magnesium alloy formed in silicate and phosphate based electrolytes, Electrochimica Acta, 54 (2009) 3842-3850. DOI: https://doi.org/10.1016/j.electacta.2009.02.004.

[14] C. Blawert, S.P. Sah, N. Scharnagl, M.B. Kannan, 8 - Plasma electrolytic oxidation/micro-arc oxidation of magnesium and its alloys, in: T.S.N.S. Narayanan, I.-S. Park, M.-H. Lee (Eds.) Surface Modification of Magnesium and its Alloys for Biomedical Applications, Woodhead Publishing, 2015, pp. 193-234.

[15] J.H. Gao, S.K. Guan, Z.W. Ren, Y.F. Sun, S.J. Zhu, B. Wang, Homogeneous corrosion of high pressure torsion treated $\mathrm{Mg}-\mathrm{Zn}-\mathrm{Ca}$ alloy in simulated body fluid, Materials Letters, 65 (2011) 691-693. DOI: https://doi.org/10.1016/j.matlet.2010.11.015.

[16] B.R. Sunil, A.A. Kumar, T.S. Sampath Kumar, U. Chakkingal, Role of biomineralization on the degradation of fine grained AZ31 magnesium alloy processed by groove pressing, Materials Science and Engineering: C, 33 (2013) 1607-1615. DOI: https://doi.org/10.1016/j.msec.2012.12.095.

[17] H. Torbati-Sarraf, S.A. Torbati-Sarraf, A. Poursaee, T.G. Langdon, Electrochemical behavior of a magnesium ZK60 alloy processed by high-pressure torsion, Corrosion Science, 154 (2019) 90-100. DOI: https://doi.org/10.1016/j.corsci.2019.04.006.

[18] D. Ahmadkhaniha, M. Fedel, M. Heydarzadeh Sohi, F. Deflorian, Corrosion behavior of severely plastic deformed magnesium based alloys: A review, Surface Engineering and Applied Electrochemistry, 53 (2017) 439-448. DOI: 10.3103/S1068375517050039.

[19] H. Wang, Y. Estrin, H. Fu, G. Song, Z. Zúberová, The Effect of Pre-Processing and Grain Structure on the Bio-Corrosion and Fatigue Resistance of Magnesium Alloy AZ31, Advanced Engineering Materials, 9 (2007) 967-972. DOI: 10.1002/adem.200700200.

[20] Y.-J. Feng, L. Wei, X.-B. Chen, M.-C. Li, Y.-F. Cheng, Q. Li, Unexpected cathodic role of $\mathrm{Mg} 41 \mathrm{Sm} 5$ phase in mitigating localized corrosion of extruded $\mathrm{Mg}-\mathrm{Sm}-\mathrm{Zn}-\mathrm{Zr}$ alloy in $\mathrm{NaCl}$ solution, Corrosion $\quad$ Science, $108133 . \quad$ DOI: https://doi.org/10.1016/j.corsci.2019.108133. 
[21] J. Meng, W. Sun, Z. Tian, X. Qiu, D. Zhang, 2 - Corrosion performance of magnesium $(\mathrm{Mg})$ alloys containing rare-earth (RE) elements, in: G.-L. Song (Ed.) Corrosion Prevention of Magnesium Alloys, Woodhead Publishing, 2013, pp. 38-60.

[22] Y. Huang, W. Gan, K.U. Kainer, N. Hort, Role of multi-microalloying by rare earth elements in ductilization of magnesium alloys, Journal of Magnesium and Alloys, 2 (2014) 17. DOI: https://doi.org/10.1016/j.jma.2014.01.005.

[23] A. Boby, A. Srinivasan, U.T.S. Pillai, B.C. Pai, Mechanical characterization and corrosion behavior of newly designed Sn and Y added AZ91 alloy, Materials \& Design, 88 (2015) 871-879. DOI: https://doi.org/10.1016/j.matdes.2015.09.010.

[24] D. Liu, D. Yang, X. Li, S. Hu, Mechanical properties, corrosion resistance and biocompatibilities of degradable Mg-RE alloys: A review, Journal of Materials Research and Technology, 8 (2019) 1538-1549. DOI: https://doi.org/10.1016/j.jmrt.2018.08.003.

[25] E. Willbold, X. Gu, D. Albert, K. Kalla, K. Bobe, M. Brauneis, C. Janning, J. Nellesen, W. Czayka, W. Tillmann, Y. Zheng, F. Witte, Effect of the addition of low rare earth elements (lanthanum, neodymium, cerium) on the biodegradation and biocompatibility of magnesium, Acta Biomaterialia, 11 (2015) 554-562. DOI: https://doi.org/10.1016/j.actbio.2014.09.041.

[26] W. Liu, F. Cao, L. Chang, Z. Zhang, J. Zhang, Effect of rare earth element Ce and La on corrosion behavior of AM60 magnesium alloy, Corrosion Science, 51 (2009) 1334-1343. DOI: https://doi.org/10.1016/j.corsci.2009.03.018.

[27] Z. Shi, F. Cao, G.-L. Song, M. Liu, A. Atrens, Corrosion behaviour in salt spray and in $3.5 \% \mathrm{NaCl}$ solution saturated with $\mathrm{Mg}(\mathrm{OH}) 2$ of as-cast and solution heat-treated binary $\mathrm{Mg}-$ RE alloys: RE=Ce, La, Nd, Y, Gd, Corrosion Science, 76 (2013) 98-118. DOI: https://doi.org/10.1016/j.corsci.2013.06.032.

[28] J. Chang, X. Guo, S. He, P. Fu, L. Peng, W. Ding, Investigation of the corrosion for Mg$\mathrm{xGd}-3 \mathrm{Y}-0.4 \mathrm{Zr}(\mathrm{x}=6,8,10,12 \mathrm{wt} \%)$ alloys in a peak-aged condition, Corrosion Science, 50 (2008) 166-177. DOI: https://doi.org/10.1016/j.corsci.2007.06.003.

[29] T. Zhang, G. Meng, Y. Shao, Z. Cui, F. Wang, Corrosion of hot extrusion AZ91 magnesium alloy. Part II: Effect of rare earth element neodymium (Nd) on the corrosion behavior of extruded alloy, Corrosion Science, 53 (2011) 2934-2942. DOI: https://doi.org/10.1016/j.corsci.2011.05.035.

[30] N. Birbilis, M.A. Easton, A.D. Sudholz, S.M. Zhu, M.A. Gibson, On the corrosion of binary magnesium-rare earth alloys, Corrosion Science, 51 (2009) 683-689. DOI: https://doi.org/10.1016/j.corsci.2008.12.012. 
[31] D. Elfiad, Y.I. Bourezg, H. Azzeddine, D. Bradai, Investigation of texture, microstructure, and mechanical properties of a magnesium-lanthanum alloy after thermomechanical processing, International Journal of Materials Research, 107 (2016) 315-323. DOI: $10.3139 / 146.111347$.

[32] J.-W. Chang, X.-W. Guo, P.-H. Fu, L.-M. Peng, W.-J. Ding, Effect of heat treatment on corrosion and electrochemical behaviour of $\mathrm{Mg}-3 \mathrm{Nd}-0.2 \mathrm{Zn}-0.4 \mathrm{Zr}$ (wt.\%) alloy, $\begin{array}{lllll}\text { Electrochimica } & \text { Acta, } & 52 & \text { (2007) } & \text { 3160-3167. }\end{array}$ https://doi.org/10.1016/j.electacta.2006.09.069.

[33] M. Curioni, F. Scenini, T. Monetta, F. Bellucci, Correlation between electrochemical impedance measurements and corrosion rate of magnesium investigated by real-time hydrogen measurement and optical imaging, Electrochimica Acta, 166 (2015) 372-384. DOI: https://doi.org/10.1016/j.electacta.2015.03.050.

[34] D.-J. Lin, F.-Y. Hung, M.-L. Yeh, H.-P. Lee, T.-S. Lui, Development of a novel microtextured surface using duplex surface modification for biomedical $\mathrm{Mg}$ alloy applications, Materials Letters, 206 (2017) 9-12. DOI: https://doi.org/10.1016/j.matlet.2017.06.047.

[35] F.H. Cao, V.H. Len, Z. Zhang, J.Q. Zhang, Corrosion behavior of magnesium and its alloy in $\mathrm{NaCl}$ solution, Russian Journal of Electrochemistry, 43 (2007) 837-843. DOI: $10.1134 / \mathrm{S} 1023193507070142$.

[36] Y.-l. Cheng, T.-w. Qin, H.-m. Wang, Z. Zhang, Comparison of corrosion behaviors of AZ31, AZ91, AM60 and ZK60 magnesium alloys, Transactions of Nonferrous Metals Society of China, 19 (2009) 517-524. DOI: https://doi.org/10.1016/S1003-6326(08)60305-2.

[37] G. Baril, N. Pébère, The corrosion of pure magnesium in aerated and deaerated sodium sulphate solutions, Corrosion Science, 43 (2001) 471-484. DOI: https://doi.org/10.1016/S0010-938X(00)00095-0.

[38] G.-L. Song, Z. Xu, Crystal orientation and electrochemical corrosion of polycrystalline Mg, Corrosion $\quad$ Science, 63 (2012) 100-112. DOI: https://doi.org/10.1016/j.corsci.2012.05.019.

[39] Y. Song, D. Shan, R. Chen, F. Zhang, E.-H. Han, Biodegradable behaviors of AZ31 magnesium alloy in simulated body fluid, Materials Science and Engineering: C, 29 (2009) 1039-1045. DOI: https://doi.org/10.1016/j.msec.2008.08.026.

[40] A.D. King, N. Birbilis, J.R. Scully, Accurate Electrochemical Measurement of Magnesium Corrosion Rates; a Combined Impedance, Mass-Loss and Hydrogen Collection Study, Electrochimica Acta, 121 (2014) 394-406. DOI: https://doi.org/10.1016/j.electacta.2013.12.124. 
[41] S. Mohajernia, S. Hejazi, A. Eslami, M. Saremi, Modified nanostructured hydroxyapatite coating to control the degradation of magnesium alloy AZ31 in simulated body fluid, Surface and Coatings Technology, 263 (2015) 54-60. DOI: https://doi.org/10.1016/j.surfcoat.2014.12.059.

[42] L. Gao, C. Zhang, M. Zhang, X. Huang, N. Sheng, The corrosion of a novel Mg-11Li3Al-0.5RE alloy in alkaline $\mathrm{NaCl}$ solution, Journal of Alloys and Compounds, 468 (2009) 285-289. DOI: https://doi.org/10.1016/j.jallcom.2007.12.080.

[43] S. Leleu, B. Rives, N. Causse, N. Pébère, Corrosion rate determination of rare-earth Mg alloys in a $\mathrm{Na} 2 \mathrm{SO} 4$ solution by electrochemical measurements and inductive coupled plasmaoptical emission spectroscopy, Journal of Magnesium and Alloys, 7 (2019) 47-57. DOI: https://doi.org/10.1016/j.jma.2018.12.002.

[44] F. Liu, Y.-w. Song, D.-y. Shan, E.-h. Han, Corrosion behavior of AZ31 magnesium alloy in simulated acid rain solution, Transactions of Nonferrous Metals Society of China, 20 (2010) s638-s642. DOI: https://doi.org/10.1016/S1003-6326(10)60553-5.

[45] Y. Song, E.-H. Han, K. Dong, D. Shan, C.D. Yim, B.S. You, Study of the corrosion product films formed on the surface of $\mathrm{Mg}-\mathrm{xZn}$ alloys in $\mathrm{NaCl}$ solution, Corrosion Science, 88 (2014) 215-225. DOI: https://doi.org/10.1016/j.corsci.2014.07.034.

[46] G.L. Song, A. Atrens, Corrosion Mechanisms of Magnesium Alloys, Advanced Engineering Materials, 1 (1999) 11-33. DOI: https://doi.org/10.1002/(SICI)15272648(199909)1:1<11::AID-ADEM11>3.0.CO;2-N.

[47] A.D. Sudholz, K. Gusieva, X.B. Chen, B.C. Muddle, M.A. Gibson, N. Birbilis, graingraing, Corrosion Science, 53 (2011) 2277-2282. DOI: https://doi.org/10.1016/j.corsci.2011.03.010.

[48] J. Yang, J. Peng, E.A. Nyberg, F.-s. Pan, Effect of Ca addition on the corrosion behavior of $\mathrm{Mg}-\mathrm{Al}-\mathrm{Mn}$ alloy, Applied Surface Science, 369 (2016) 92-100. DOI: https://doi.org/10.1016/j.apsusc.2016.01.283.

[49] W.T. Huo, W. Zhang, J.W. Lu, Y.S. Zhang, Simultaneously enhanced strength and corrosion resistance of $\mathrm{Mg}-3 \mathrm{Al}-1 \mathrm{Zn}$ alloy sheets with nano-grained surface layer produced by sliding friction treatment, Journal of Alloys and Compounds, 720 (2017) 324-331. DOI: https://doi.org/10.1016/j.jallcom.2017.05.258.

[50] I.B. Singh, M. Singh, S. Das, A comparative corrosion behavior of Mg, AZ31 and AZ91 alloys in 3.5\% NaCl solution, Journal of Magnesium and Alloys, 3 (2015) 142-148. DOI: https://doi.org/10.1016/j.jma.2015.02.004. 
[51] J. Li, Q. Jiang, H. Sun, Y. Li, Effect of heat treatment on corrosion behavior of AZ63 magnesium alloy in 3.5wt.\% sodium chloride solution, Corrosion Science, 111 (2016) 288301. DOI: https://doi.org/10.1016/j.corsci.2016.05.019.

[52] X. Zhao, L.-1. Shi, J. Xu, A Comparison of Corrosion Behavior in Saline Environment: Rare Earth Metals (Y, Nd, Gd, Dy) for Alloying of Biodegradable Magnesium Alloys, Journal of Materials Science \& Technology, 29 (2013) 781-787. DOI: https://doi.org/10.1016/j.jmst.2013.05.017.

[53] L.L. Rokhlin, Magnesium Alloys Containing Rare Earth Metals: Structure and Properties, Taylor \& Francis, 2003.

[54] N.N. Aung, W. Zhou, Effect of grain size and twins on corrosion behaviour of AZ31B magnesium alloy, Corrosion Science, 52 (2010) 589-594. DOI: https://doi.org/10.1016/j.corsci.2009.10.018.

[55] K. Gusieva, C.H.J. Davies, J.R. Scully, N. Birbilis, Corrosion of magnesium alloys: the role of alloying, International Materials Reviews, 60 (2015) 169-194. DOI: 10.1179/1743280414Y.0000000046.

[56] L. Rokhlin, Magnesium Alloys Containing Rare Earth Metals, Taylor and Francis, (2003).

[57] J. Liu, Y. Song, J. Chen, P. Chen, D. Shan, E.-H. Han, The Special Role of Anodic Second Phases in the Micro-galvanic Corrosion of EW75 Mg Alloy, Electrochimica Acta, 189 (2016) 190-195. DOI: https://doi.org/10.1016/j.electacta.2015.12.075.

[58] Y. Song, D. Shan, E.-H. Han, Pitting corrosion of a Rare Earth Mg alloy GW93, Journal of Materials Science \& Technology, 33 (2017) 954-960. DOI: https://doi.org/10.1016/j.jmst.2017.01.014.

[59] C. Cai, R. Song, L. Wang, J. Li, Effect of anodic T phase on surface micro-galvanic corrosion of biodegradable Mg-Zn-Zr-Nd alloys, Applied Surface Science, 462 (2018) 243254. DOI: https://doi.org/10.1016/j.apsusc.2018.08.107.

[60] R.J.M. Konings, O. Beneš, A. Kovács, D. Manara, D. Sedmidubský, L. Gorokhov, V.S. Iorish, V. Yungman, E. Shenyavskaya, E. Osina, The Thermodynamic Properties of the fElements and their Compounds. Part 2. The Lanthanide and Actinide Oxides, Journal of Physical and Chemical Reference Data, 43 (2014) 013101. DOI: 10.1063/1.4825256.

[61] H. Altun, S. Sen, Studies on the influence of chloride ion concentration and $\mathrm{pH}$ on the corrosion and electrochemical behaviour of AZ63 magnesium alloy, Materials \& Design, 25 (2004) 637-643. DOI: https://doi.org/10.1016/j.matdes.2004.02.002. 


\section{Figure captions}

Figure 1: SEM images of the initial microstructure with low and high resolution of: $(a, b)$ $\mathrm{Mg}-0.3 \mathrm{Ce}$, (c, d) Mg-0.41Dy, (e, f) Mg-0.63Gd, (g, h) Mg-1.44Nd and (i, j) Mg-1.43La alloys.

Figure 2: Potentiodynamic polarization curves in $3.5 \% \mathrm{NaCl}$ solution for the $\mathrm{Mg}-0.3 \mathrm{Ce}, \mathrm{Mg}-$ 0.41Dy, Mg-0.63Gd, Mg-1.44Nd and Mg-1.43La alloys.

Figure 3: Nyquist plots for the $\mathrm{Mg}-0.3 \mathrm{Ce}, \mathrm{Mg}-0.41 \mathrm{Dy}, \mathrm{Mg}-0.63 \mathrm{Gd}, \mathrm{Mg}-1.44 \mathrm{Nd}$ and $\mathrm{Mg}-$ 1.43La alloys after $2 \mathrm{~h}$ in $3.5 \% \mathrm{NaCl}$ solution.

Figure 4: Equivalent electric circuit of $\mathrm{Mg}-\mathrm{RE}$ alloys immersed in 3.5\% $\mathrm{NaCl}$ solution: a) Mg-0.41Dy, b) Mg-0.3Ce, Mg-0.63Gd and Mg-1.44Nd and c) Mg-1.43La alloys.

Figure 5: Photographs of the $\mathrm{Mg}-0.41 \mathrm{Dy}$ and $\mathrm{Mg}-1.43 \mathrm{La}$ alloys surface as a function of immersion time in $3.5 \% \mathrm{NaCl}$ solution: $(\mathrm{a}, \mathrm{c}) 2 \mathrm{~h}$ and $(\mathrm{b}, \mathrm{d}) 24 \mathrm{~h}$.

Figure 6: Cross-section images obtained by optical microscopy of the alloys after immersion for $24 \mathrm{~h}$ in $3.5 \% \mathrm{NaCl}$ solution: (a) $\mathrm{Mg}-0.41 \mathrm{Dy}$ alloy and (b) $\mathrm{Mg}-1.43 \mathrm{La}$ alloy.

Figure 7: SEM micrographs showing corrosion morphologies of Mg-0.41Dy alloy after immersion in $3.5 \% \mathrm{NaCl}$ solution for: (a, b) $2 \mathrm{~h}$ and (c, d) $24 \mathrm{~h}$.

Figure 8: SEM micrographs showing corrosion morphologies of $\mathrm{Mg}-1.43 \mathrm{La}$ alloy after immersion in a $3.5 \% \mathrm{NaCl}$ solution for: (a, b) $2 \mathrm{~h}$ and (c, d) $24 \mathrm{~h}$.

Figure 9: SEM micrograph showing the mushrooms like shaped precipitation on the surface of the $\mathrm{Mg}-0.41 \mathrm{Dy}$ alloy after immersion for $24 \mathrm{~h}$ in $3.5 \% \mathrm{NaCl}$ solution.

Figure 10: XPS survey spectra after $120 \mathrm{~s}$ Ar etching for Mg-0.41Dy (a, b) and Mg-1.43La (c, d) alloy after immersion in 3.5\% $\mathrm{NaCl}$ solution for 2 and $24 \mathrm{~h}$, respectively.

Figure 11: XRD patterns of as-cast and immersed samples of: a) $\mathrm{Mg}-0.41 \mathrm{Dy}$ and b) $\mathrm{Mg}$ 1.43La alloys.

Figure 12: SEM images and chemical element mapping of the cross-sections of Mg-0.41Dy alloy after $24 \mathrm{~h}$ of immersion in $3.5 \% \mathrm{NaCl}$ solution.

Figure 13: SEM images and chemical element mapping of the cross-sections of $\mathrm{Mg}-1.43 \mathrm{La}$ alloy after $24 \mathrm{~h}$ of immersion in $3.5 \% \mathrm{NaCl}$ solution. 


\section{Table captions}

Table 1: EDS analysis in weight percentage in several positions in the microstructures of ascast Mg-RE alloys (from Fig. 1).

Table 2. Fitting parameters of the potentiodynamic polarization curves of $\mathrm{Mg}-\mathrm{RE}$ alloy in $3.5 \% \mathrm{NaCl}$ solution.

Table 3. Electrochemical parameters obtained from the fits of the experimental EIS data of Mg-RE alloys in $3.5 \% \mathrm{NaCl}$ solution.

Table 4. EDS analysis in weight percentage (wt. \%) in several positions in the microstructure of immersed Mg-0.41Dy alloy for $24 \mathrm{~h}$ in $3.5 \% \mathrm{NaCl}$ solution (from Fig. 9).

Table 5. Elemental composition (in atomic percentage) of the corrosion product in $\mathrm{Mg}-0.41$ and $\mathrm{Mg}-1.43 \mathrm{La}$ alloys after immersion for $2 \mathrm{~h}$ and $24 \mathrm{~h}$ in $3.5 \% \mathrm{NaCl}$ solution, respectively.

Table 6. Specific physicochemical properties of the $R E$ elements used in the present work [53]. 


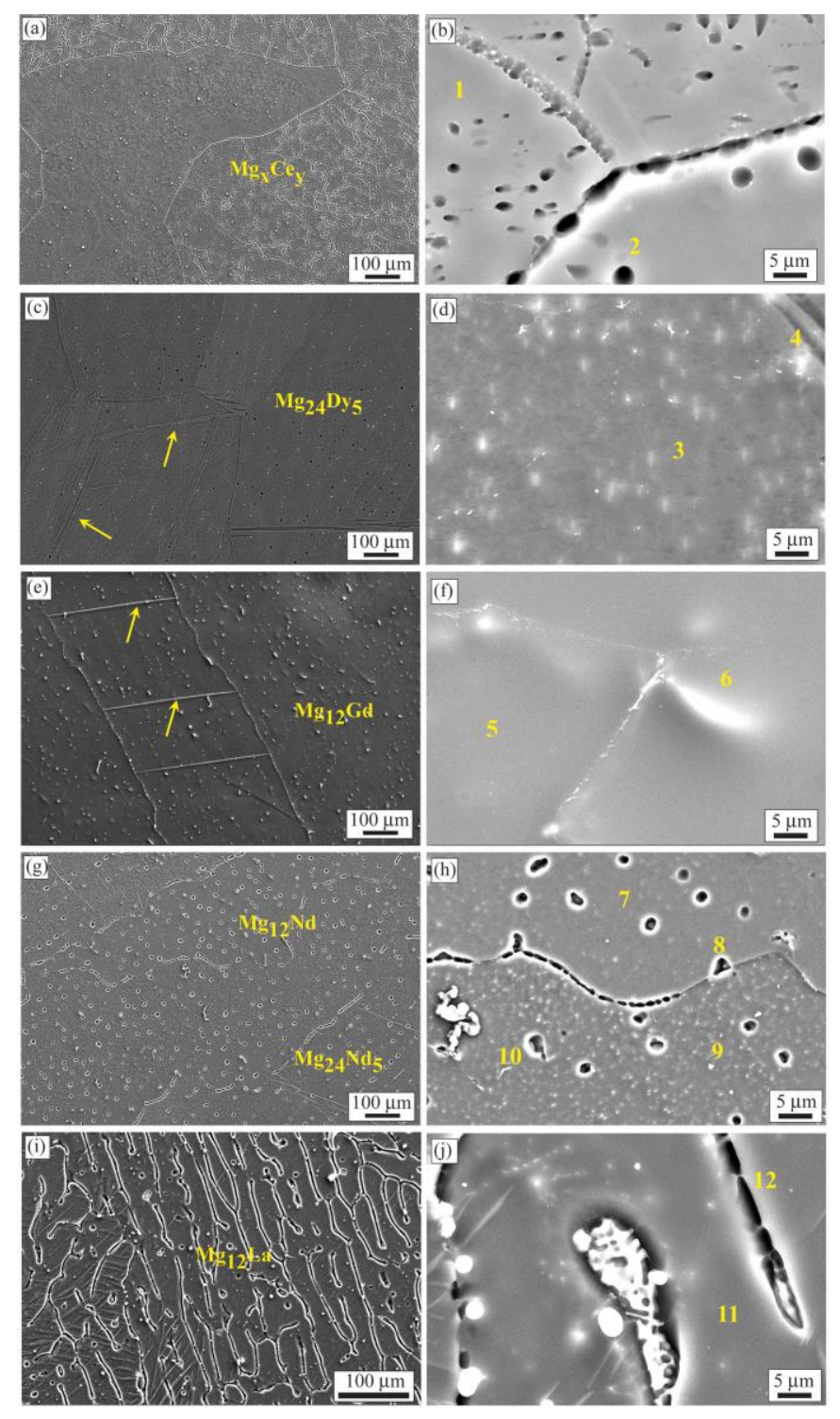

Figure 1 


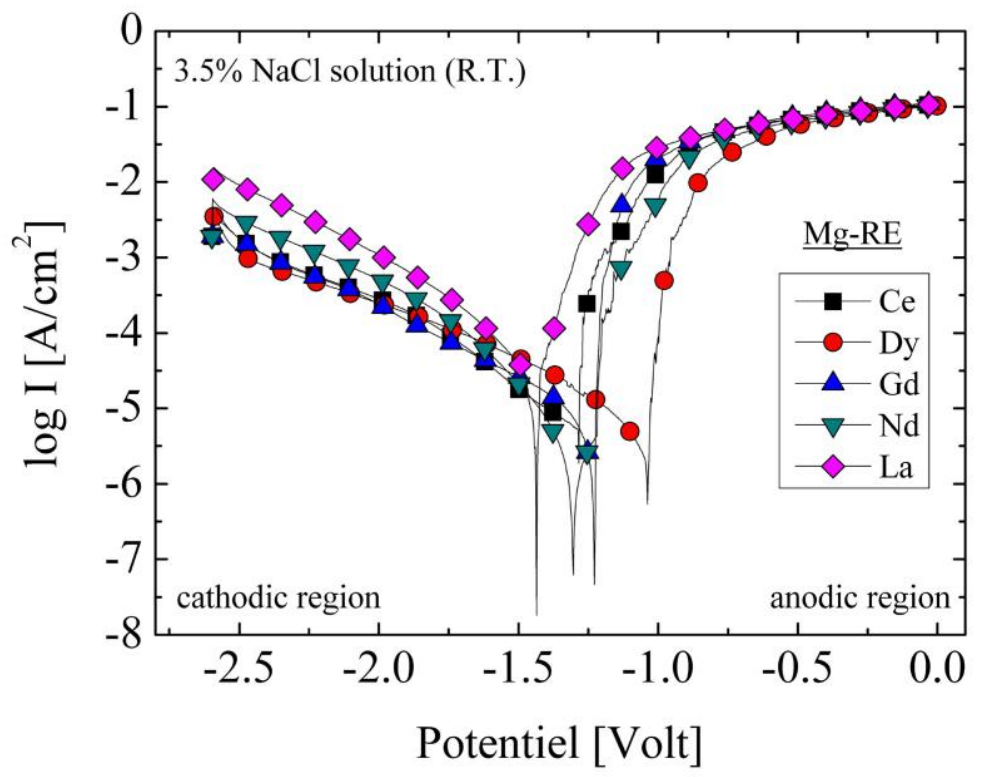

Figure 2

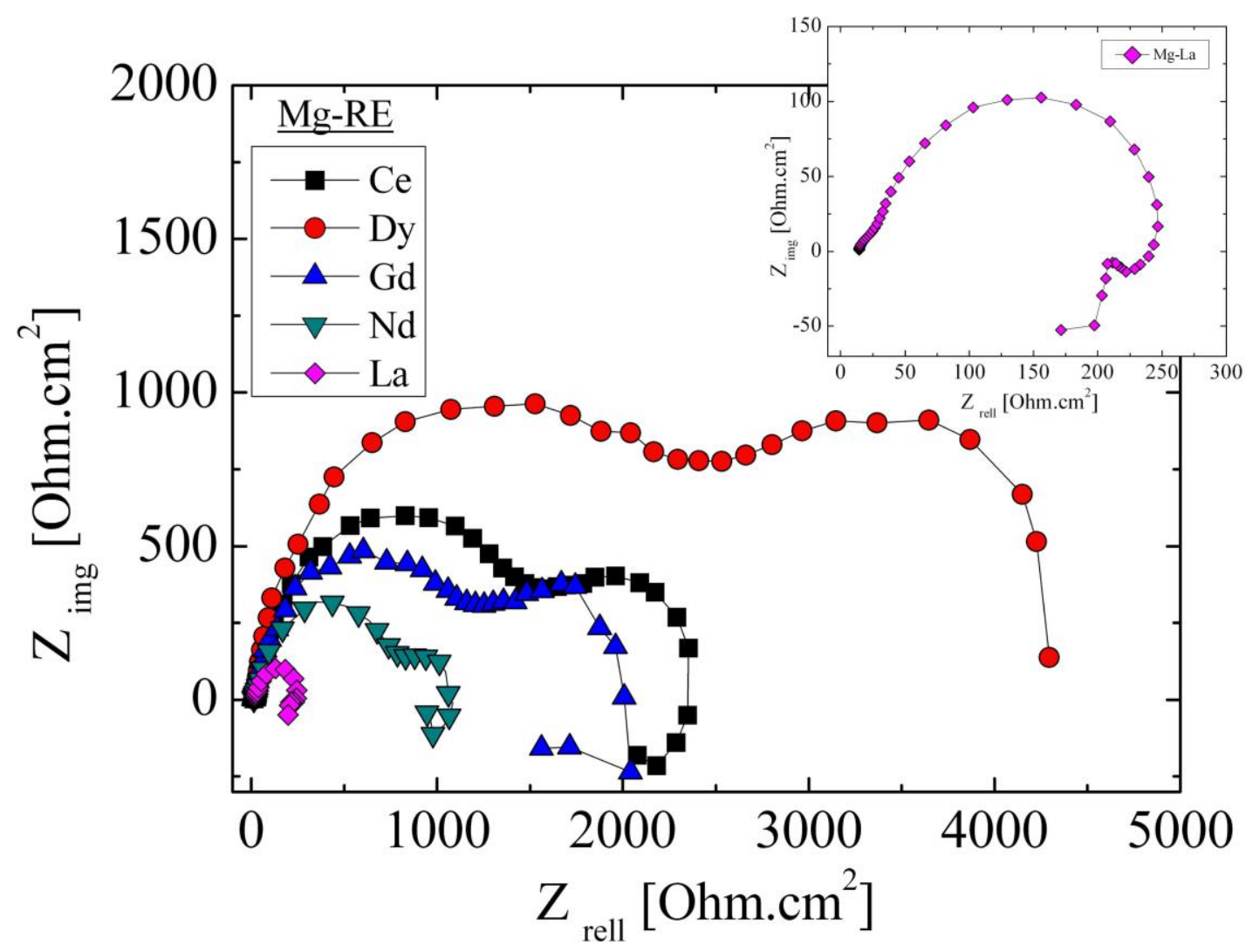

Figure 3 
(a)

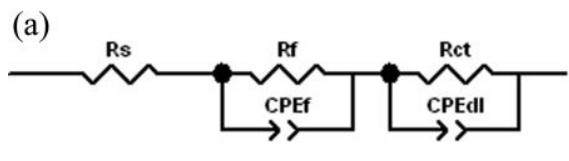

(b)

(c)

Figure 4

$3.5 \% \mathrm{NaCl}$ solution
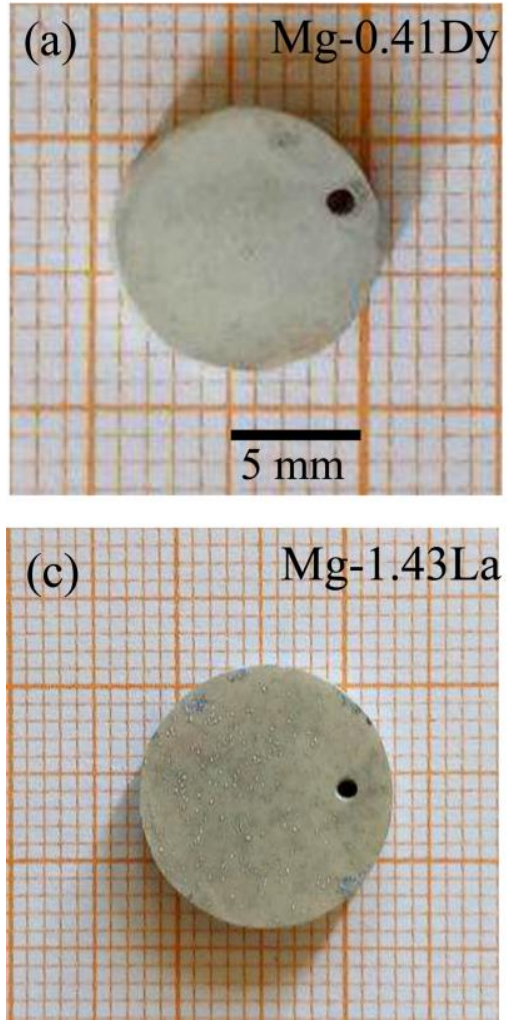

Figure 5
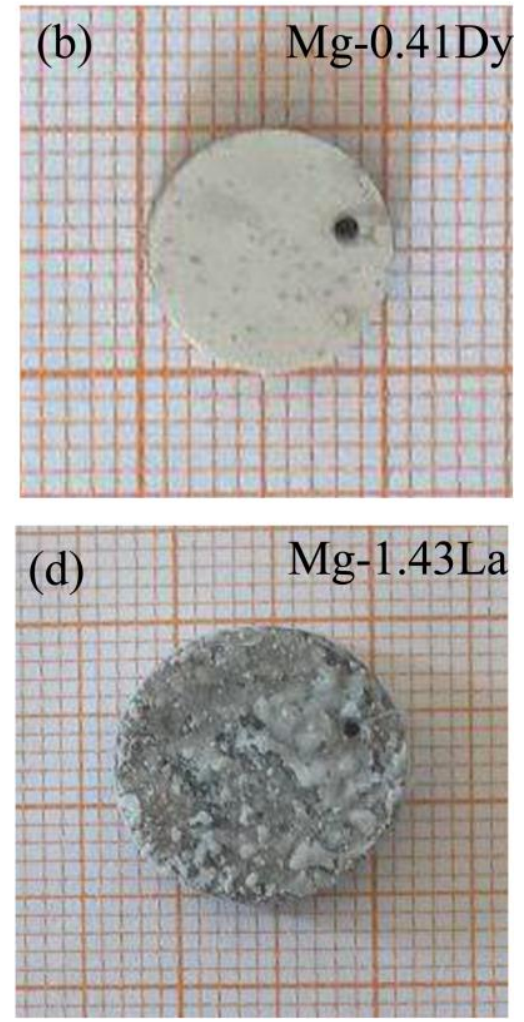

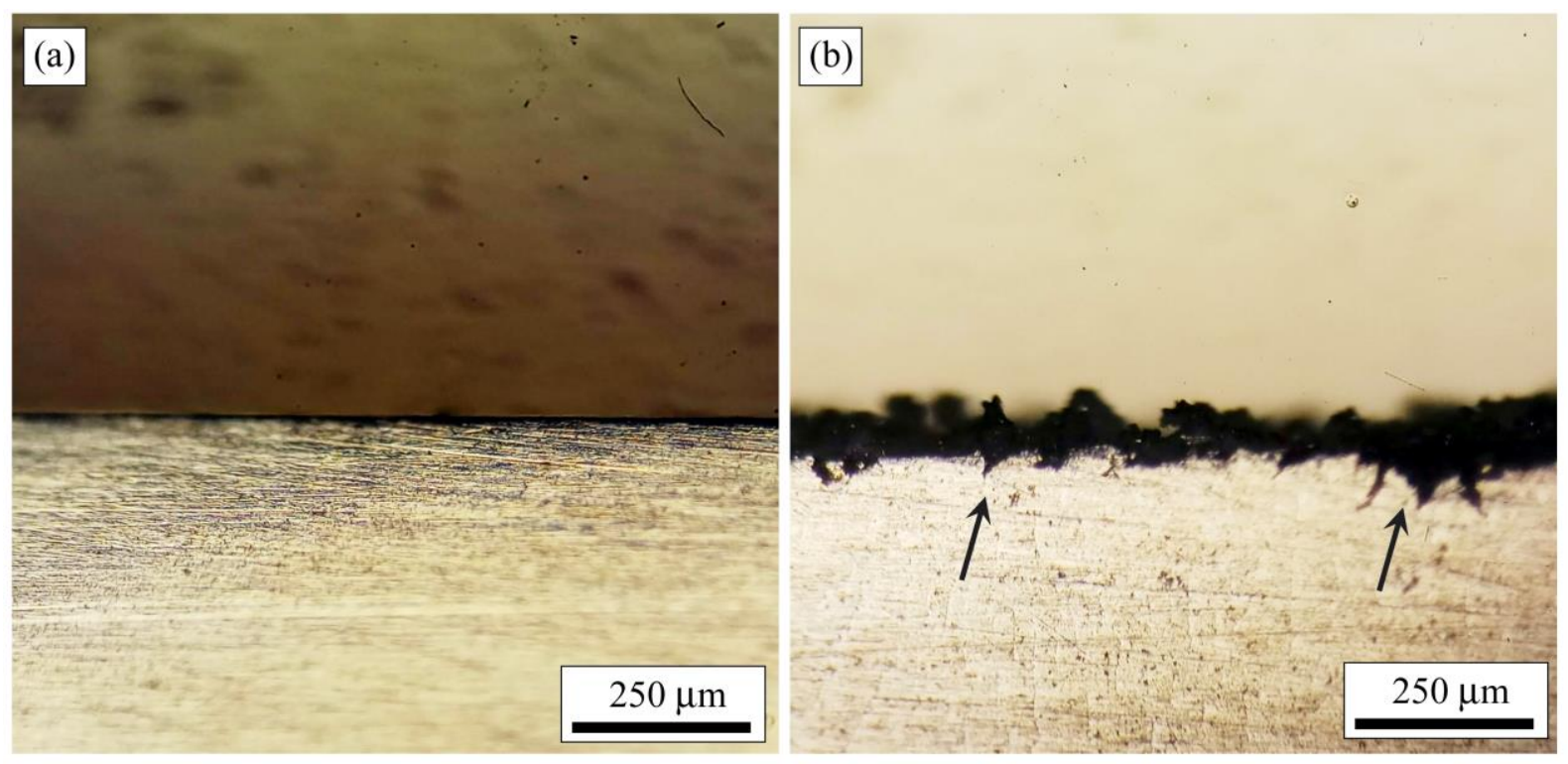

Figure 6

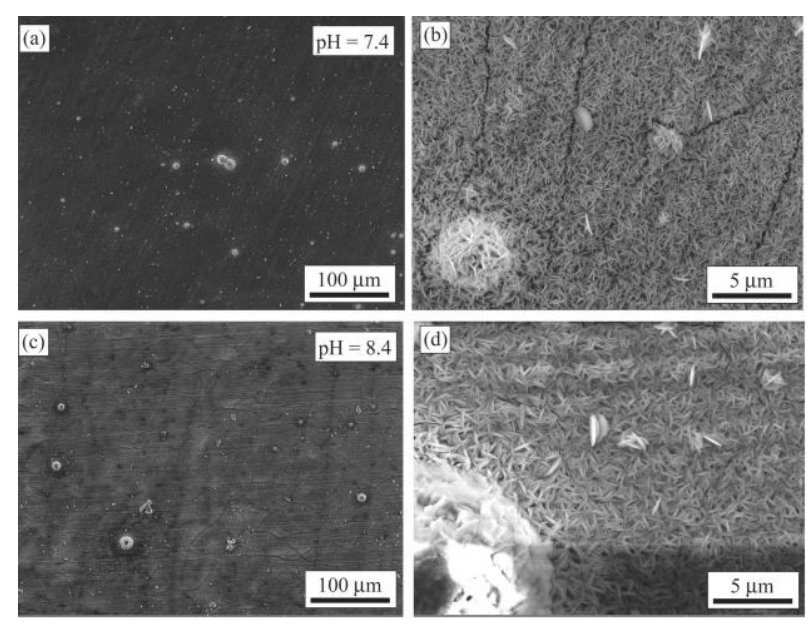

Figure 7 

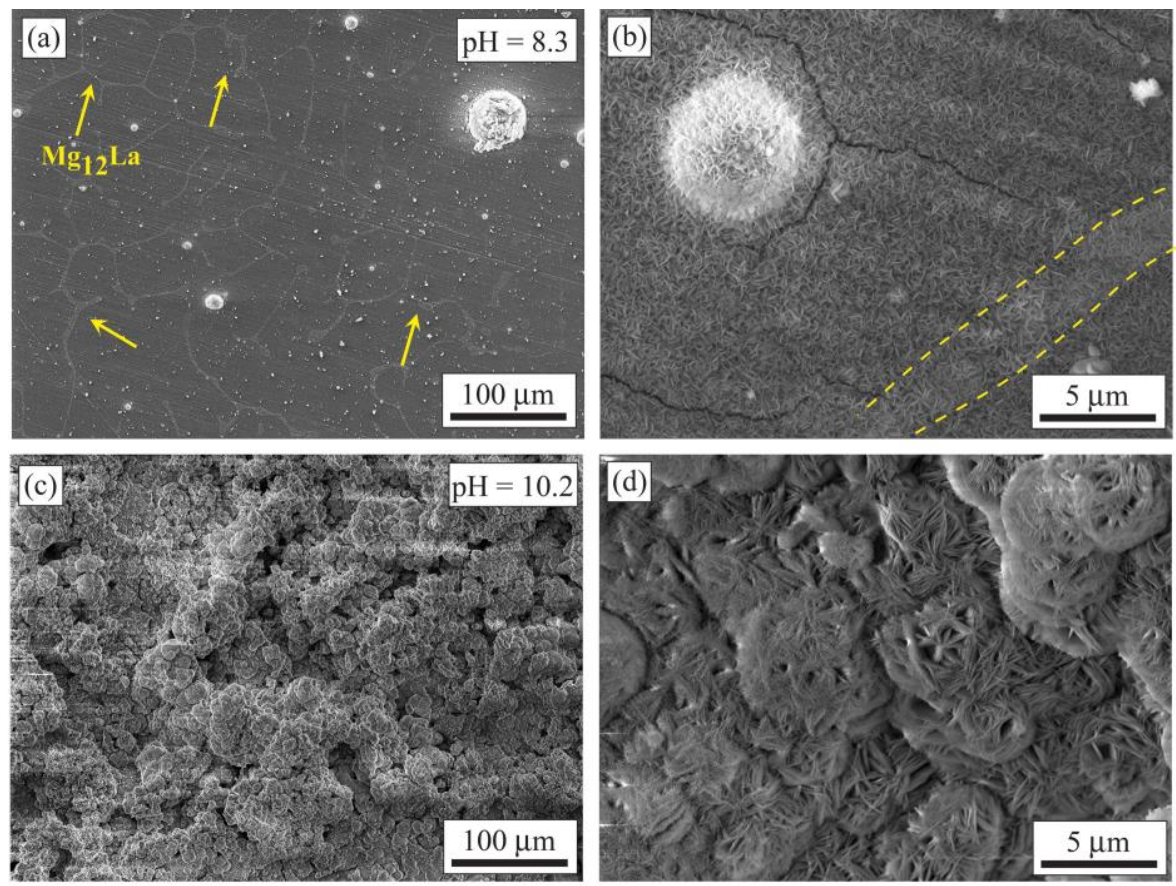

Figure 8

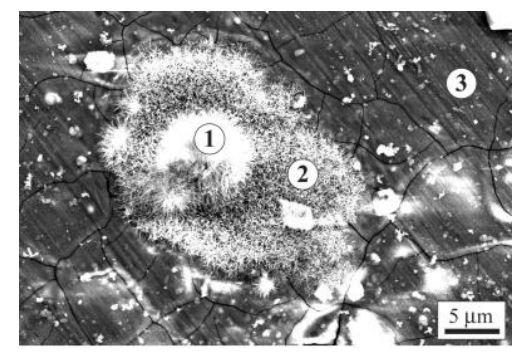

Figure 9 
(a)

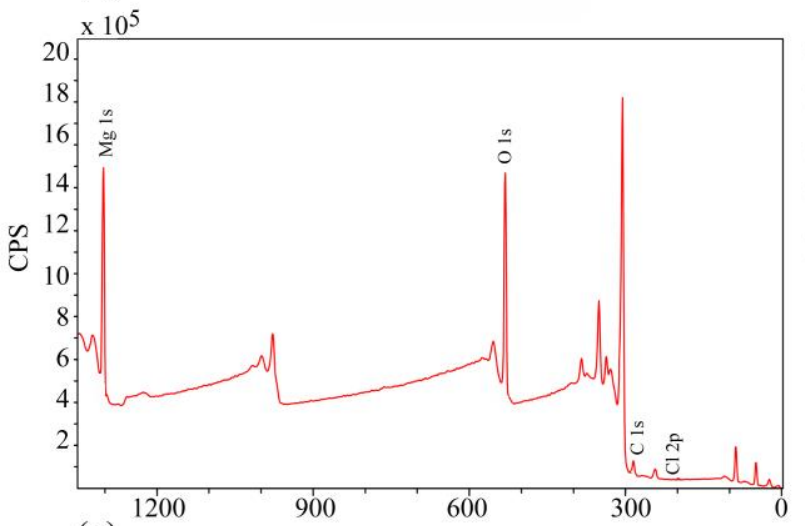

(c)

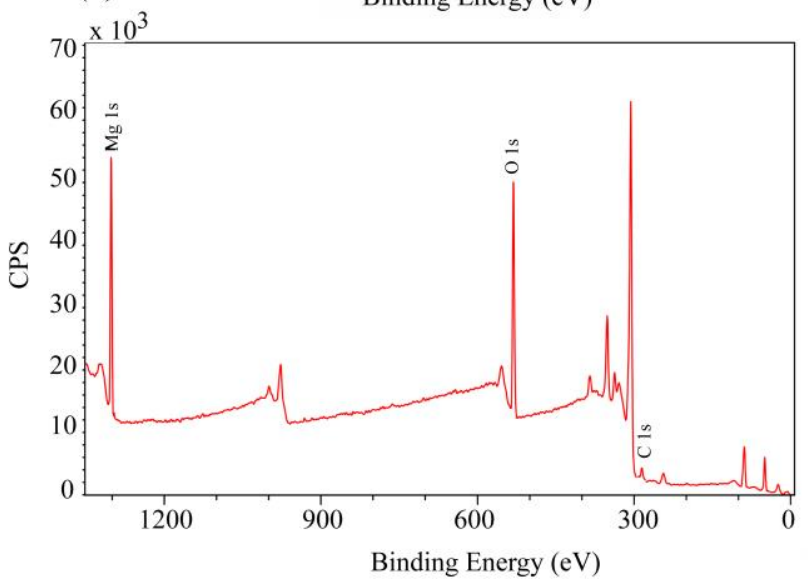

(b)

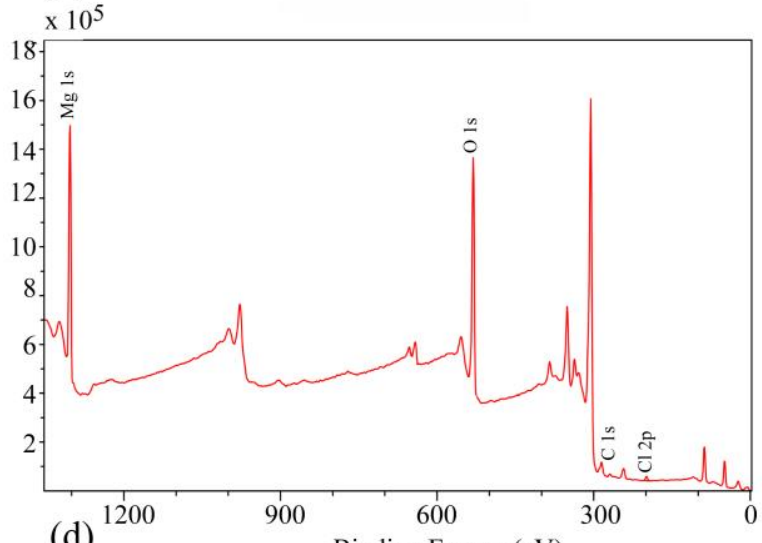

(d) Binding Energy (eV)

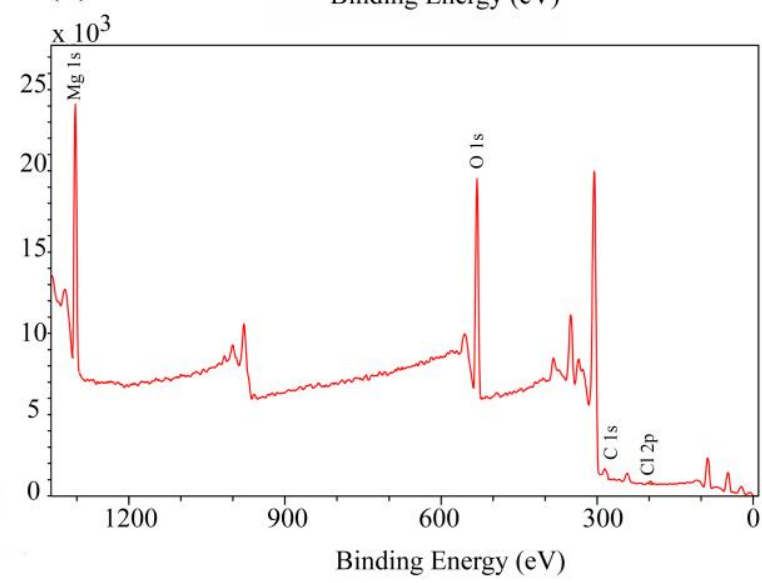

Figure 10
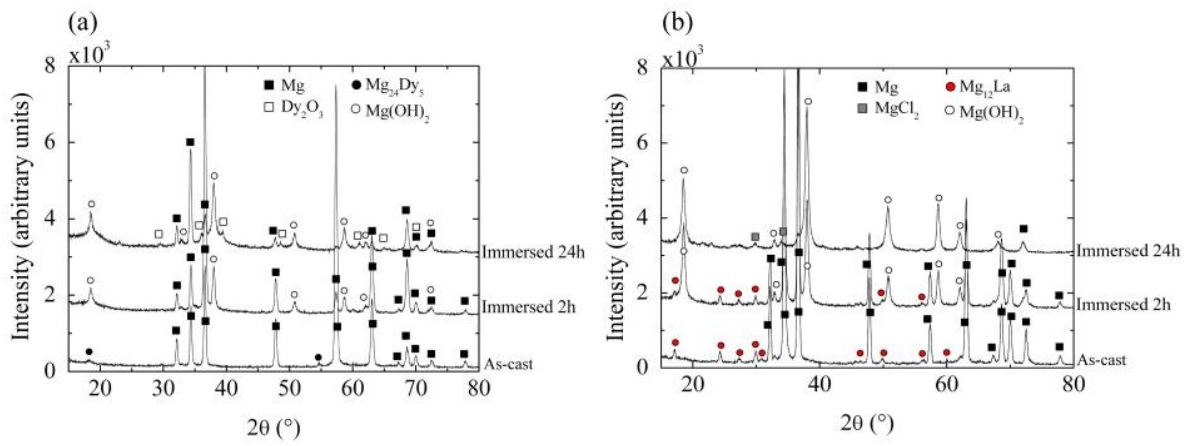

Figure 11 


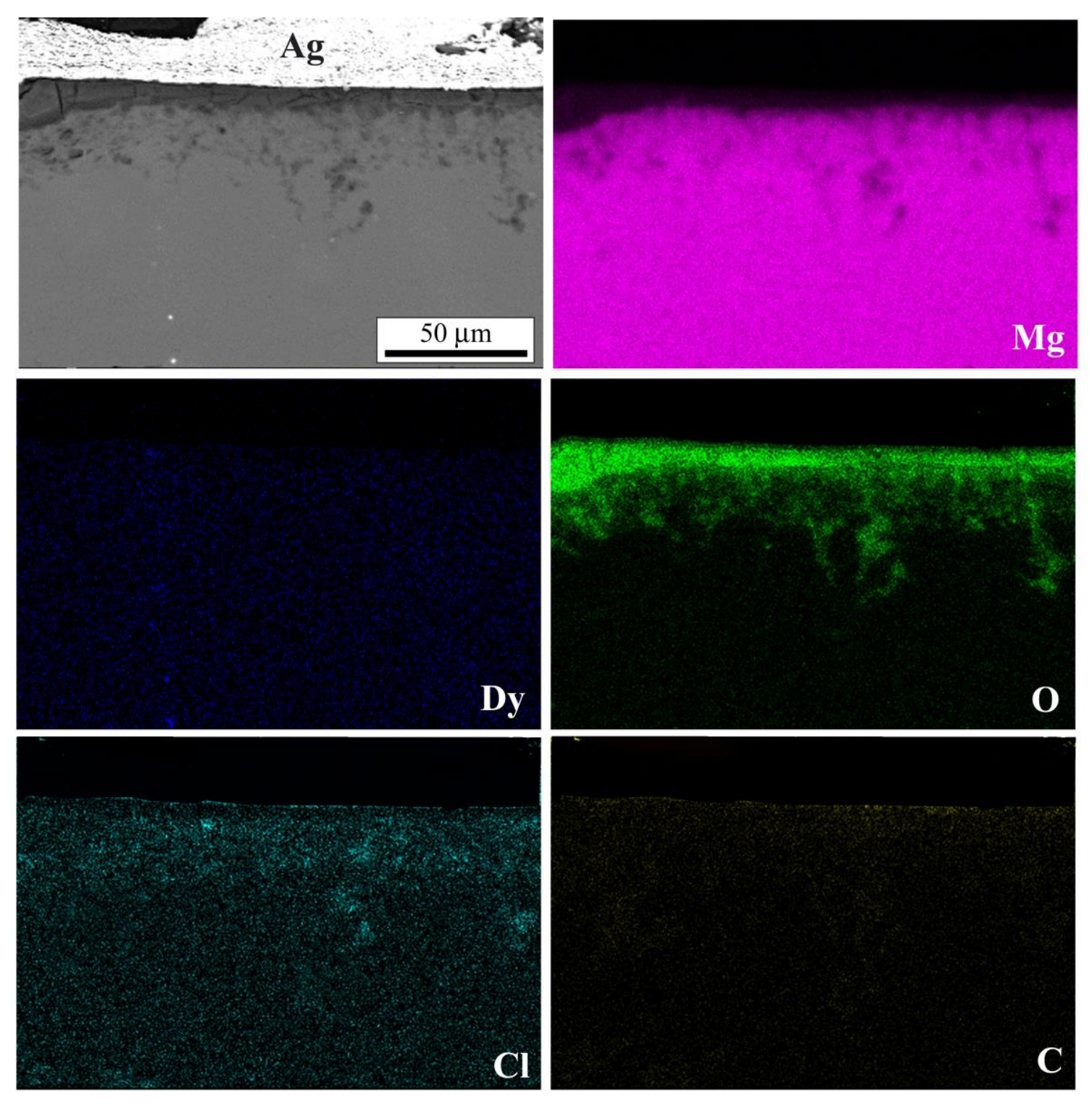

Figure 12 

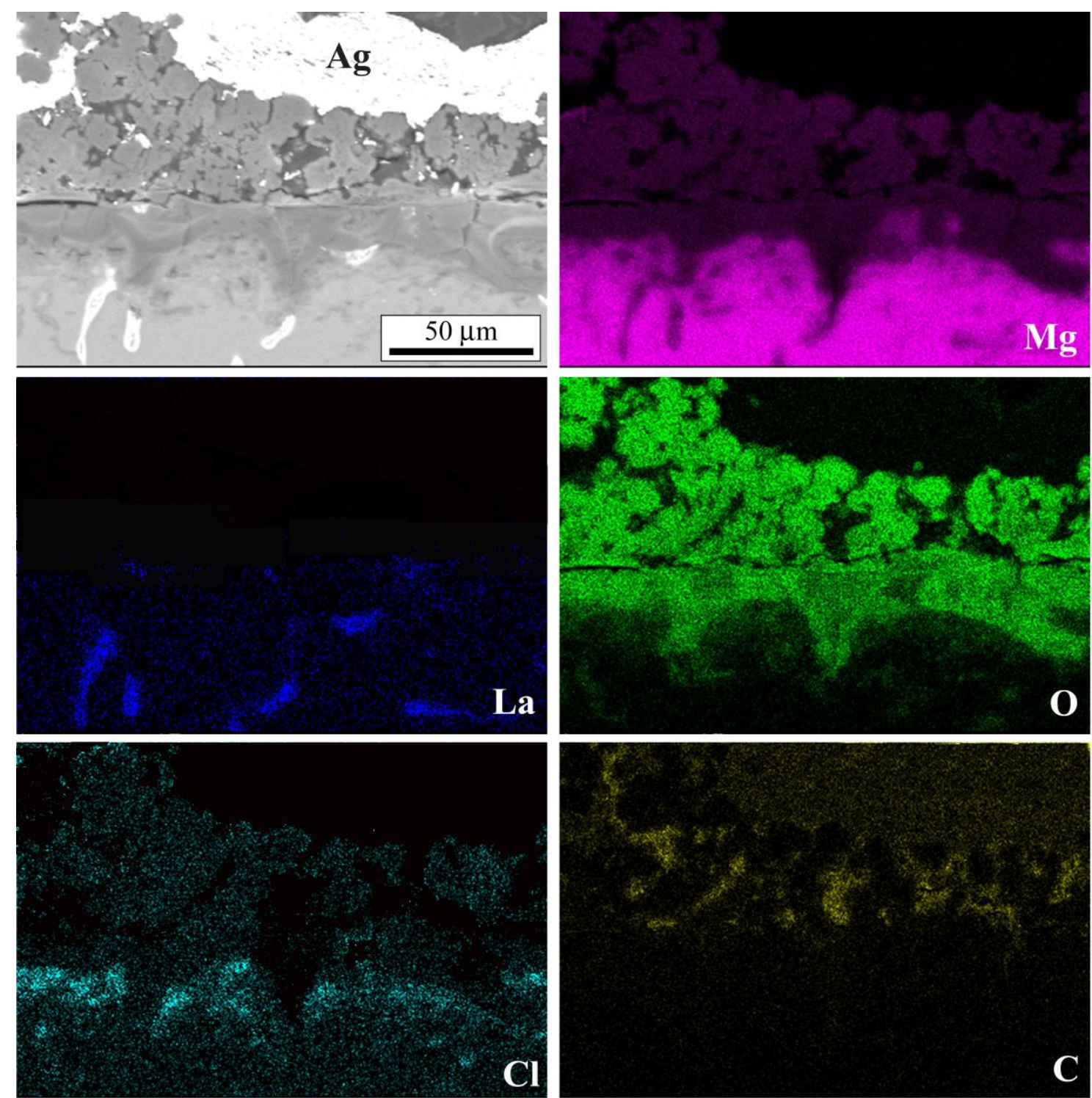

Figure 13

Table 1: EDS analysis in weight percentage in several positions in the microstructures of ascast Mg-RE alloys (from Fig. 1).

\begin{tabular}{cccccccc}
\hline Position Number & $\mathrm{Mg}$ & $\mathrm{Ce}$ & $\mathrm{Dy}$ & $\mathrm{Gd}$ & $\mathrm{Nd}$ & $\mathrm{La}$ & Phase composition \\
\hline$\frac{\mathrm{Mg}-0.3 \mathrm{Ce}}{1}$ & 99.8 & 0.2 & - & - & - & - & $\alpha-\mathrm{Mg}$ \\
2 & 90.79 & 9.21 & - & - & - & - & $\mathrm{Mg}_{\mathrm{x}} \mathrm{Ce}_{\mathrm{y}}$ \\
$\frac{\mathrm{Mg}-0.41 \mathrm{Dy}}{3}$ & & & & & & & \\
4 & 99.45 & - & 0.55 & - & - & - & $\alpha-\mathrm{Mg}$ \\
$\frac{\mathrm{Mg}-0.63 \mathrm{Gd}}{5}$ & 43.48 & - & 56.52 & - & - & - & $\mathrm{Mg}_{24} \mathrm{Dy} 5$ \\
\hline & 99.19 & - & - & 0.81 & - & - & $\alpha-\mathrm{Mg}$ \\
\hline
\end{tabular}




\begin{tabular}{cccccccc}
\hline 6 & 66.7 & - & - & 33.3 & - & - & $\mathrm{Mg}_{12} \mathrm{Gd}$ \\
$\frac{\mathrm{Mg}-1.44 \mathrm{Nd}}{7}$ & & & & & & & \\
8 & 98.53 & - & - & - & 1.47 & - & $\alpha-\mathrm{Mg}$ \\
9 & 63.74 & - & - & - & 36.26 & - & $\mathrm{Mg}_{12} \mathrm{Nd}$ \\
10 & 56.36 & - & - & - & 43.64 & - & $\mathrm{Mg}_{41} \mathrm{Nd}_{5}$ \\
$\frac{\mathrm{Mg}-1.43 \mathrm{La}}{11}$ & 80.48 & - & - & - & 19.59 & - & $\mathrm{Mg}_{24} \mathrm{Nd}$ \\
12 & 98.19 & - & - & - & - & 1.81 & $\alpha-\mathrm{Mg}$ \\
\hline
\end{tabular}

Table 2. Fitting parameters of the potentiodynamic polarization curves of Mg-RE alloy in $3.5 \% \mathrm{NaCl}$ solution.

\begin{tabular}{cccccc}
\hline Alloy & $\mathrm{E}_{\text {corr }}(\mathrm{V})$ & $\mathrm{I}_{\text {corr }}\left(\mathrm{A} . \mathrm{cm}^{-2}\right)$ & $\beta_{\mathrm{a}}(\mathrm{V})$ & $\beta_{\mathrm{c}}(\mathrm{V})$ & $\mathrm{R}_{\mathrm{p}}\left(\Omega . \mathrm{cm}^{2}\right)$ \\
\hline $\mathrm{Mg}-0.41 \mathrm{Dy}$ & -1.25 & 0.0096 & 0.15 & -0.69 & 5.58 \\
$\mathrm{Mg}-0.3 \mathrm{Ce}$ & -1.54 & 0.0138 & 0.22 & -0.60 & 5.12 \\
$\mathrm{Mg}-0.63 \mathrm{Gd}$ & -1.52 & 0.0120 & 0.18 & -0.58 & 5.02 \\
$\mathrm{Mg}-1.44 \mathrm{Nd}$ & -1.68 & 0.0215 & 0.37 & -0.57 & 4.55 \\
$\mathrm{Mg}-1.43 \mathrm{La}$ & -1.80 & 0.0420 & 0.48 & -0.66 & 2.89 \\
\hline
\end{tabular}


Table 3. Electrochemical parameters obtained from the fits of the experimental EIS data of Mg-RE alloys in 3.5\% $\mathrm{NaCl}$ solution.

\begin{tabular}{|c|c|c|c|c|c|c|c|c|c|c|}
\hline \multirow[t]{2}{*}{ Alloys } & \multirow[t]{2}{*}{$\mathrm{R}_{\mathrm{s}}\left(\Omega . \mathrm{cm}^{2}\right)$} & \multirow[t]{2}{*}{$\mathrm{R}_{\mathrm{ct}}\left(\Omega . \mathrm{cm}^{2}\right)$} & \multicolumn{2}{|c|}{$\mathrm{CPE}_{\mathrm{dl}}\left(\mathrm{F} . \mathrm{cm}^{-2}\right)$} & \multirow[t]{2}{*}{$\mathrm{R}_{\mathrm{f}}\left(\Omega \cdot \mathrm{cm}^{2}\right)$} & \multicolumn{2}{|c|}{$\mathrm{CPE}_{\mathrm{f}}\left(\mathrm{F} . \mathrm{cm}^{-2}\right)$} & \multirow[t]{2}{*}{$\mathrm{L}_{1}\left(\mathrm{H}_{\mathrm{cm}} \mathrm{cm}^{-2}\right)$} & \multirow[t]{2}{*}{$\mathrm{R}_{\mathrm{L}}\left(\Omega \cdot \mathrm{cm}^{2}\right)$} & \multirow[t]{2}{*}{$\mathrm{L}_{2}\left(\mathrm{H} \mathrm{cm}^{-2}\right)$} \\
\hline & & & $Y$ & $n$ & & $Y$ & $n$ & & & \\
\hline $\mathrm{Mg}-0.41 \mathrm{Dy}$ & 15.06 & 2400 & $2.60 \times 10^{-5}$ & 0.85 & 3568 & 0.00085 & 0.85 & - & - & - \\
\hline $\mathrm{Mg}-0.3 \mathrm{Ce}$ & 12.79 & 1203 & $2.64 \times 10^{-5}$ & 0.91 & 2749 & 0.00118 & 0.47 & 15876 & 1069 & - \\
\hline $\mathrm{Mg}-0.63 \mathrm{Gd}$ & 13.24 & 986 & $2.84 \times 10^{-5}$ & 0.88 & 1993 & 0.0013 & 0.53 & 10228 & 844 & - \\
\hline $\mathrm{Mg}-1.44 \mathrm{Nd}$ & 12.39 & 611 & $3.47 \times 10^{-5}$ & 0.89 & 769.9 & 0.0016 & 0.42 & 5586 & 482.8 & - \\
\hline $\mathrm{Mg}-1.43 \mathrm{La}$ & 13.67 & 13.28 & $5.16 \times 10^{-5}$ & 0.79 & 429.1 & $2.38 \times 10^{-5}$ & 0.84 & 131 & 1400 & 12968 \\
\hline
\end{tabular}


Table 4. EDS analysis in weight percentage (wt. \%) in several positions in the microstructure of immersed $\mathrm{Mg}-0.41 \mathrm{Dy}$ alloy for $24 \mathrm{~h}$ in $3.5 \% \mathrm{NaCl}$ solution (from Fig. 9).

\begin{tabular}{cccc}
\hline Position Number & $\mathrm{O}$ (wt. \%) & $\mathrm{Mg}$ (wt. \%) & $\mathrm{Cl}$ (wt. \%) \\
\hline 1 & 48.13 & 35.10 & 16.77 \\
2 & 45.21 & 40.59 & 14.20 \\
3 & 47.01 & 50.03 & 2.95 \\
\hline
\end{tabular}

Table 5. Elemental composition (in atomic percentage) of the corrosion product in $\mathrm{Mg}-0.41$ and $\mathrm{Mg}$-1.43 La alloys after immersion for $2 \mathrm{~h}$ and $24 \mathrm{~h}$ in $3.5 \% \mathrm{NaCl}$ solution, respectively.

\begin{tabular}{lllll}
\hline Sample & $\mathrm{Mg}$ (at.\%) & $\mathrm{O}$ (at.\%) & $\mathrm{C}$ (at.\%) & $\mathrm{Cl}$ (at.\%) \\
\hline$\underline{\text { Mg-0.41Dy }}$ & & & & \\
2h of immersion & 22.16 & 65.35 & 12.11 & 0.38 \\
24h of immersion & 21.46 & 65.08 & 11.00 & 1.14 \\
Mg-1.43La & & & & \\
2h of immersion & 20.36 & 65.80 & 13.57 & - \\
24h of immersion & 23.62 & 65.74 & 9.78 & 0.86 \\
\hline
\end{tabular}

Table 6. Specific physicochemical properties of the $R E$ elements used in the present work [53].

\begin{tabular}{|c|c|c|c|c|c|}
\hline $\begin{array}{c}R E \\
\text { element }\end{array}$ & $\begin{array}{l}\text { Atomic } \\
\text { number }\end{array}$ & $\begin{array}{l}\text { Atomic mass } \\
(\mathrm{g} / \mathrm{mol})\end{array}$ & $\begin{array}{c}\text { Electron } \\
\text { configuration }\end{array}$ & Electronegativity & $\begin{array}{l}\text { Density } \\
\left(\mathrm{g} / \mathrm{cm}^{3}\right)\end{array}$ \\
\hline $\mathrm{La}$ & 57 & 138.9 & {$[\mathrm{Xe}] 5 d^{1} 6 s^{2}$} & 1.17 & 6.14 \\
\hline $\mathrm{Ce}$ & 58 & 140.12 & {$[\mathrm{Xe}] 4 f^{1} 5 d^{1} 6 s^{2}$} & 1.21 & 7 \\
\hline $\mathrm{Nd}$ & 60 & 144.24 & {$[\mathrm{Xe}] 4 f^{4} 6 s^{2}$} & 1.19 & 7 \\
\hline $\mathrm{Gd}$ & 64 & 157.25 & {$[\mathrm{Xe}] 4 f^{7} 5 d^{1} 6 s^{2}$} & 1.2 & 7.9 \\
\hline Dy & 66 & 162.93 & {$[\mathrm{Xe}] 4 f^{10} 6 s^{2}$} & 1.21 & 8.55 \\
\hline
\end{tabular}


